\title{
Middle East and Central Asia: A Survey of Gender Budgeting Efforts
}




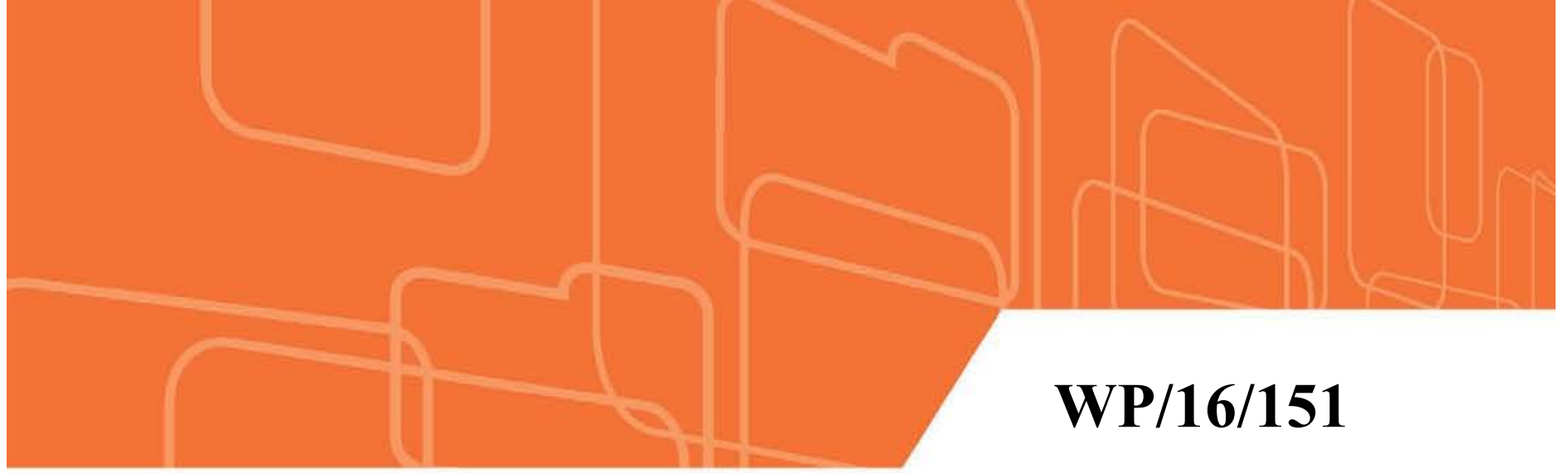

\section{IMF Working Paper}

Middle East and Central Asia:

A Survey of Gender Budgeting Efforts

By Lisa Kolovich and Sakina Shibuya

I N T ER N A T I O N A L M O N E T A R Y FU N D 


\title{
IMF Working Paper
}

Strategy, Policy, and Review and Research Departments

\section{Middle East and Central Asia: A Survey of Gender Budgeting Efforts Prepared by Lisa Kolovich and Sakina Shibuya*}

Authorized for distribution by Prakash Loungani and Catherine Pattillo

July 2016

\begin{abstract}
IMF Working Papers describe research in progress by the author(s) and are published to elicit comments and to encourage debate. The views expressed in IMF Working Papers are those of the author(s) and do not necessarily represent the views of the IMF, its Executive Board, or IMF management.
\end{abstract}

\begin{abstract}
Gender budgeting uses fiscal policies to promote gender equality and women's advancement, but is struggling to take hold in the Middle East and Central Asia. We provide an overview of two gender budgeting efforts in the region-Morocco and Afghanistan. Achievements in these two countries include increasing female primary and secondary education enrollment rates and reducing maternal mortality. But the region not only needs to use fiscal policies for women's advancement, but also reform tax and financial laws, enforce laws that assure women's safety in public, and change laws that prevent women from taking advantage of employment opportunities.
\end{abstract}

JEL Classification Numbers: H00, I3, J16

Keywords: Gender budgeting; fiscal policy and administration; gender inequality; Middle East and Central Asia

Authors’ Email Addresses: 1kolovich@imf.org; sshibuya@imf.org

\footnotetext{
* IMF. We are grateful to Janet Stotsky, Diane Elson, Mario Mansour, Mark Blackden, Yamini Mishra, Sheena Kanwar, Nalini Burn, Chris Jarvis, Alexei Kireyev, Richard Allen, and participants at the Center of Excellence in Finance in Slovenia 2016 Roundtable on Gender Budgeting for helpful comments. We also thank Sandra Stotsky for editorial comments. This paper is part of a research project on macroeconomic policy in low-income countries and is supported by the the United Kingdom's Department for International Development (DFID). It does not necessarily represent the views of the International Monetary Fund or of DFID.
} 


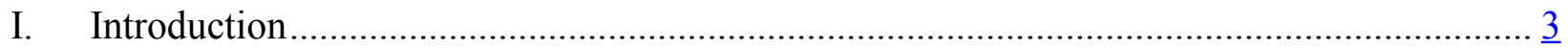

II. Overview of the Middle East and Central Asia Region.................................................. 4

III. Fiscal Context for Gender Budgeting ...................................................................... $\underline{8}$

IV. Effective Gender Budgeting Initiatives in the Middle East and Central Asia Region .......... 11

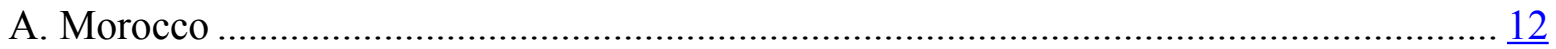

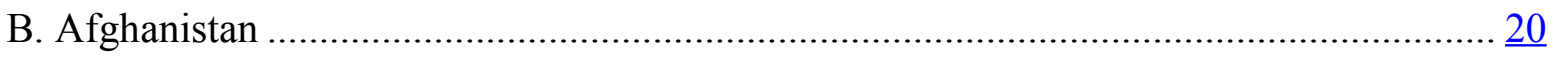

V. Other Gender-related Initiatives in the Middle East and Central Asia ............................. 24

VI. Gender Budgeting in the Current Macroeconomic Situation ......................................... 28

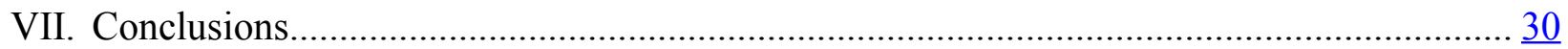

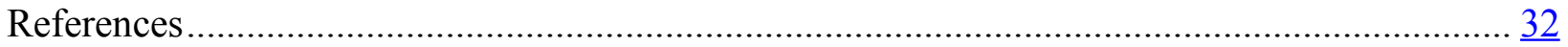

Tables

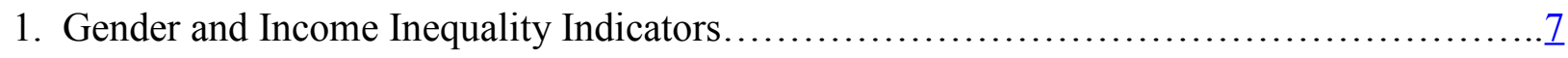

2. Fiscal Indicators and Public Expenditure and Financial Accountability.................... 9

Figures

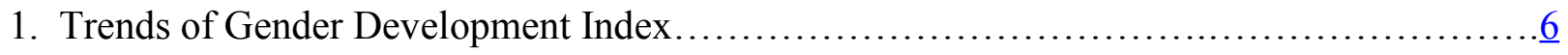

2. Trends in Gender Inequality in Morocco and its Regional Counterparts ............................ 18

3. Education Enrollment and Illiteracy Rates by Gender and Rural/Urban Area...............19

4. Trends in Gender Inequality in Afghanistan and its Regional Counterparts ........................ 23

5. Total Revenues, Expenditures, and Tax Revenues in Oil Exporting Countries (average over

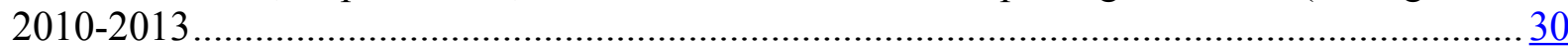

Boxes

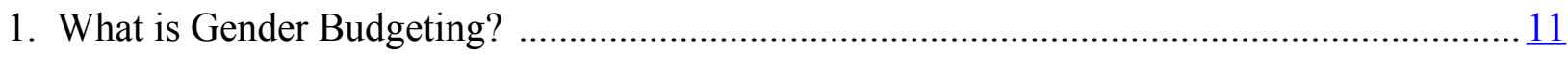

2. Evidence on Gender Inequality and Growth in the Middle East and Central Asia ............... 17

3. Gender Inequality and Revenues in Oil-Exporting Countries ........................................ Appendices

A. Indicators of the Gender-Oriented Millennium Development Goals................................. $\underline{38}$

B. Gender Budgeting in the Middle East and Central Asia Data Template ............................. $\underline{39}$ 


\section{INTRODUCTION}

Gender budgeting, an initiative that uses fiscal policies and administration to address gender inequality and women's advancement, is struggling to take hold in the Middle East and Central Asia. ${ }^{1}$ And despite recent progress in improving conditions for women and girls, gender inequality remains entrenched in most of these countries. This paper overviews gender budgeting initiatives in this region and focuses on the two most well-developed initiatives, Morocco and Afghanistan. It assesses whether gender budgeting is contributing to gender equality and women's advancement and suggests ways countries can address these goals. This review is part of a larger research project on gender budgeting, which surveys and assesses experiences across the world. ${ }^{2}$

The first gender budgeting initiatives in the region date back to the early 2000s and differ in their origins, frameworks, and goals. Early on, Morocco and Afghanistan aligned their objectives with the Millennium Development Goals ${ }^{3}$ and their own national development plans, thus prioritizing budgetary spending in areas where there was broad agreement on specific targets to improve women's health care and opportunities for education and paid employment. In each country, the Ministry of Finance played an essential role in guiding the process and ensuring key spending ministries were on board with the initiative. These countries also sought to improve sexdisaggregated data collection to inform fiscal decision-making. Furthermore, they benefited from the support of international organizations, such as UN Women (formerly UNIFEM), and nongovernmental organizations, parliamentarians, and academicians.

After assessing the regional evidence, we see that while Morocco has made progress in key gender equality indicators, it still lags its regional counterparts. Afghanistan made more progress on gender equality and women's advancement than its international comparators, but it is difficult to isolate the effect of gender budgeting from other initiatives in this post-conflict country.

In our view, the region can improve its use of fiscal policies to address gender inequality and women's advancement. It can learn not only from its own attempts at gender budgeting but also from the efforts of other regions. The countries in the region need to ensure that both girls and boys have similar opportunities for primary and secondary education and women and men for appropriate health care. This is particularly true in low-income and developing countries in this region, which, compared to other low-income and developing nations in sub-Saharan Africa,

\footnotetext{
${ }^{1}$ The Middle East and Central Asia encompasses two distinct sub-regions, the countries of the Middle East and North Africa (MENA) and the Caucasus and Central Asian Republics of the former Soviet Union (CCA), with a few countries not fitting easily into either sub-region.

${ }^{2}$ See an overview in Stotsky (2016).

${ }^{3}$ Appendix A provides a list of indicators corresponding to each gender-oriented Millennium Development Goal.
} 
Asia and the Pacific, and the Americas and Caribbean, have lower levels of female secondary school enrollment (Stotsky et al., 2016).

Because of the continuing low rate of women's participation in paid employment despite rising education levels in most Middle Eastern countries, fiscal policies should address whatever hindrances there may be to women's labor force participation, such as inadequate day care for children, the absence of help for elder care, and higher effective tax rates on secondary earners in the household. Targeted subsidies to employers may help overcome the reluctance of employers to employ women and break down cultural barriers to women in the workplace.

There continue to be discriminatory tax and financial laws in many of the countries' legal systems as well as legal barriers constraining women's right to work in nearly every country in the Middle East and North Africa (World Bank, 2015a). In addition, domestic violence against women remains a problem in most countries, and their judicial systems cannot address this problem adequately, although Algeria and Morocco are now trying to tackle this issue. Changes in the law are not always adequately enforced to ensure reforms achieve their intended effect.

The structure for the rest of this paper is as follows. Section II offers an overview of gender inequality and women's advancement, including recent changes, in the Middle East and Central Asia. Section III places gender budgeting in the context of national fiscal policies. Section IV presents studies of Morocco and Afghanistan, drawing upon national authorities, scholarly published sources, and reports by other organizations that have provided aid to the region. Using the best evidence at our disposal, the section assesses how well gender budgeting initiatives are being implemented. In Section V, we summarize the Egyptian experience with gender budgeting as well as gender-oriented initiatives in other countries in the region, some of which are not referred to as gender budgeting by the countries themselves. In Section VI, we suggest how the current situation in the region, now challenged by low oil prices and other economic and political instabilities, could affect the implementation of budget-based programs for gender equality and women's advancement. In Section VII, we offer recommendations on the way forward.

\section{OVERVIEW OF THE MIDDle EAST AND CENTRAL ASIA REgion}

There are 31 countries in the Middle East and Central Asia region. The majority are emerging markets, while nine are low-income developing countries, according to the IMF classification of countries ${ }^{4}$ Despite their different histories and characteristics, we can place the countries in the Middle East and North Africa and those in Central Asia into two broad groups for our analysis.

\footnotetext{
${ }^{4}$ In the Middle East, the low-income and developing countries are Afghanistan, Djibouti, Mauritania, Somalia, Sudan, and Yemen; in Central Asia, the low-income and developing countries are the Kyrgyz Republic, Tajikistan, and Uzbekistan. Emerging markets in the Middle East are Algeria, Bahrain, Egypt, Iran, Iraq, Jordan, Kuwait, Lebanon, Libya, Morocco, Oman, Qatar, Saudi Arabia, Syrian Arab Republic, Tunisia, and the United Arab
} 
Political conflicts and civil unrest have afflicted many countries in the Middle East in recent years (IMF, 2014; World Bank, 2015b). Starting in 2010, political change, driven in large part by social and political tensions, spread across more than 10 countries in the Middle East and North Africa. Unemployment rates are high in the region, particularly for women and youth, and a lack of access to infrastructure leads to further disadvantages for women, particularly those in rural areas (IMF, 2014). Many Arab countries (Egypt, Jordan, Libya, Morocco, Tunisia, and Yemen) have begun or plan to increase spending on infrastructure, healthcare, and education, but also need changes in tax policies, civil service requirements, and public financial management (Jewell et al., 2016).

Nine of the states in the Middle East and North Africa region are classified by the IMF as "fragile states": Afghanistan, Iraq, Libya, Somalia, South Sudan, Sudan, Syria, West Bank and Gaza, and Yemen. A country is deemed to be fragile if it has weak institutional capacity or has experienced conflict in the last three years (IMF, 2015a). Fragile states tend to face poorer macroeconomic conditions than non-fragile states, and the evidence suggests that women in particular encounter more difficult conditions, including sexual violence, in fragile states (World Health Organization, 2015).

Compared to the Middle East and North Africa region, the Caucasus and Central Asia countries have enjoyed strong but volatile growth over the last 15 years, although they can be prone to external shocks. However, since 2014, the growth of countries in the Caucasus and Central Asia has been negatively affected by lower commodity prices and spillovers from the slowdown in Russia's growth (IMF, 2015b).

Gender budgeting efforts are motivated by a combination of considerations, including basic a sense of fairness and the view that a greater role for women in economic and public life has the potential to contribute significantly to economic growth and stability in the region. Eliminating gender inequalities can lead to better health outcomes for women and children, increased female labor force participation, and faster economic growth, and fairer and more stable societies (World Bank, 2011).

Figure 1 shows the continuing stark gender inequality in the region, and the notable progress most of the countries have achieved in recent years. At the aggregate level, gender equality, measured by the Gender Development Index (GDI), ${ }^{5}$ is improving for both sub-regions. While

Emirates; Central Asian emerging markets are Armenia, Azerbaijan, Georgia, Kazakhstan, and Turkmenistan. The West Bank and Gaza is not a member state and is therefore not included in the IMF income classification. The regional classification scheme follows that used by the IMF in its Middle Eastern and Central Asian Department.

${ }^{5}$ The GDI was initially developed by the United Nations Development Program (UNDP). Stotsky et al. (2016) construct the UNDP's current GDI backward consistently in time to 1980, and denote this as the "time consistent" calculation. The index captures gender gaps in three critical components of equality: health, knowledge, and living standards. 
all countries have made improvements since the early 1990s, a few countries, including Afghanistan, lag behind their counterparts.

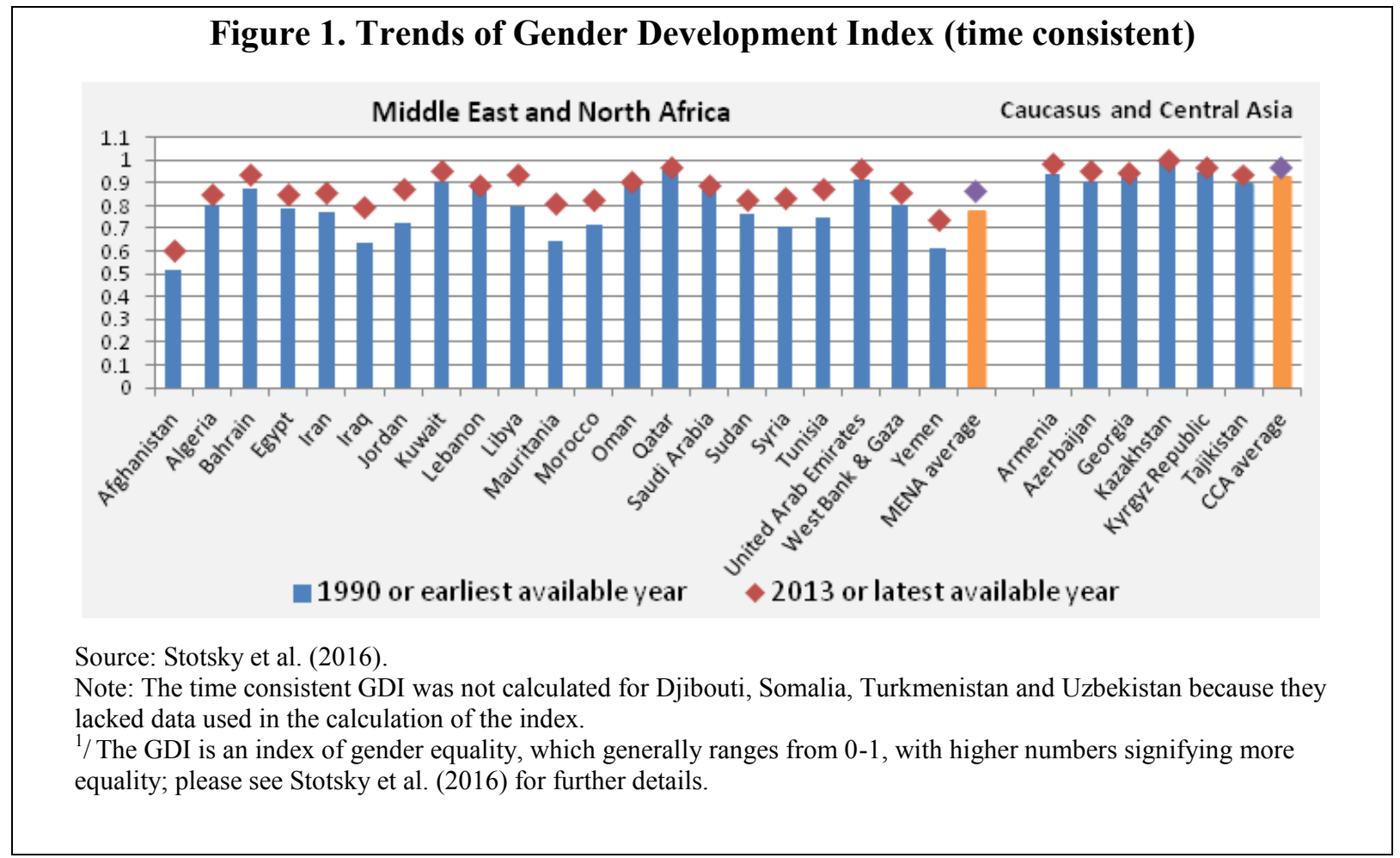

Table 1 shows additional measures of gender inequality. In both sub-regions, females constitute a large proportion of secondary school enrollment, on average. However, there are exceptionally low female secondary school enrollments as a share of the total in some countries in the Middle East and North Africa (Afghanistan, Djibouti, Iraq, Mauritania, Somalia, and Yemen). On the other hand, some countries have a larger proportion of female than male secondary school enrollments, a growing trend across the world. ${ }^{6}$

\footnotetext{
${ }^{6}$ In some of these countries, the female secondary enrollment rate is over 100 percent, suggesting that there are grade repeaters or late or early enrollments. For more information, please refer to https://datahelpdesk.worldbank.org/knowledgebase/articles/1 14955-how-can-gross-school-enrollment-ratios-beover-100.
} 
Table 1. Gender and Income Inequality Indicators

\begin{tabular}{|c|c|c|c|c|c|c|c|c|c|}
\hline Country & $\begin{array}{c}\text { GDI } \\
\text { (Time }_{\text {consistent) }}^{1}\end{array}$ & $\begin{array}{c}\text { Gini } \\
\text { coefficient }^{2} \\
(\text { scale } 0-100)\end{array}$ & $\begin{array}{c}\text { Gross secondary } \\
\text { enrollment } \\
\text { (female/ male } \\
\text { ratio) }\end{array}$ & $\begin{array}{c}\text { Gross } \\
\text { secondary } \\
\text { enrollment } \\
\text { (female) }\end{array}$ & $\begin{array}{c}\text { Labor force } \\
\text { participation rate } \\
\text { (female/male } \\
\text { ratio) }\end{array}$ & $\begin{array}{c}\text { Labor force } \\
\text { participation } \\
\text { rate (female) }\end{array}$ & $\begin{array}{c}\text { Maternal } \\
\text { mortality } \\
\text { ratio } \\
\text { (per 100,000) }\end{array}$ & $\begin{array}{c}\text { Legislation } \\
\text { exists on } \\
\text { domestic } \\
\text { violence }\end{array}$ & $\begin{array}{c}\text { Married men } \\
\text { and women have } \\
\text { equal property } \\
\text { ownership rights }\end{array}$ \\
\hline Afghanistan & 0.601 & n.a. & 0.55 & 38.3 & 0.20 & 16.2 & 400 & No & No \\
\hline Algeria & 0.848 & 35.3 & 1.04 & 99.5 & 0.21 & 16.2 & 89 & No & Yes \\
\hline Bahrain & 0.938 & n.a. & 1.02 & 96.6 & 0.46 & 40.7 & 22 & No & Yes \\
\hline Djibouti & n.a. ${ }^{3}$ & 45.1 & 0.77 & 40.1 & 0.55 & 38.5 & 230 & No & Yes \\
\hline Egypt, Arab Rep. & 0.854 & 30.8 & 0.98 & 85.5 & 0.33 & 25.8 & 45 & No & Yes \\
\hline Iran, Islamic Rep. & 0.861 & 37.4 & 0.94 & 83.4 & 0.23 & 17.6 & 23 & No & Yes \\
\hline Iraq & 0.797 & 29.5 & 0.75 & 45.3 & 0.22 & 15.6 & 67 & No & Yes \\
\hline Jordan & 0.871 & 33.7 & 1.03 & 89.0 & 0.24 & 16.4 & 50 & Yes & Yes \\
\hline Kuwait & 0.956 & n.a. & 1.01 & 100.7 & 0.53 & 45.1 & 14 & No & Yes \\
\hline Lebanon & 0.893 & n.a. & 1.01 & 74.3 & 0.34 & 25.9 & 16 & No & Yes \\
\hline Libya & 0.937 & n.a. & 1.18 & 113.0 & 0.40 & 31.8 & 15 & n.a. & n.a. \\
\hline Mauritania & 0.808 & 37.5 & 0.85 & 24.5 & 0.37 & 29.4 & 320 & No & No \\
\hline Morocco & 0.829 & 40.7 & 0.86 & 63.4 & 0.34 & 27.1 & 120 & No & Yes \\
\hline Oman & 0.909 & n.a. & 0.95 & 95.3 & 0.36 & 30.5 & 11 & No & Yes \\
\hline Qatar & 0.967 & n.a. & 1.10 & 117.2 & 0.54 & 51.8 & 6 & No & Yes \\
\hline Saudi Arabia & 0.890 & n.a. & 1.01 & 116.7 & 0.27 & 21.3 & 16 & No & Yes \\
\hline Somalia & n.a. & n.a. & 0.46 & 4.6 & 0.50 & 38.8 & 850 & n.a. & n.a. \\
\hline Sudan & 0.823 & 35.4 & n.a. & n.a. & 0.43 & 32.6 & 360 & No & Yes \\
\hline Syrian Arab Republic & 0.839 & 35.8 & 1.00 & 74.6 & 0.19 & 14.3 & 49 & No & Yes \\
\hline Tunisia & 0.877 & 35.8 & 1.05 & 93.3 & 0.36 & 27.3 & 46 & No & Yes \\
\hline United Arab Emirates & 0.964 & n.a. & 1.10 & 87.6 & 0.51 & 46.8 & 8 & No & Yes \\
\hline West Bank and Gaza & 0.862 & 34.5 & 1.10 & 86.7 & 0.23 & 16.1 & 47 & No & Yes \\
\hline Yemen, Rep. & 0.738 & 35.9 & 0.65 & 36.9 & 0.36 & 26.4 & 270 & No & Yes \\
\hline MENA average & 0.860 & 35.9 & 0.93 & 75.7 & 0.35 & 28.3 & 134 & & \\
\hline Armenia & 0.984 & 31.5 & 1.21 & 106.2 & 0.77 & 58.4 & 29 & No & Yes \\
\hline Azerbaijan & 0.951 & 16.6 & 0.99 & 99.5 & 0.93 & 68.1 & 26 & Yes & Yes \\
\hline Georgia & 0.949 & 40.0 & 0.95 & 87.2 & 0.77 & 60.6 & 41 & Yes & Yes \\
\hline Kazakhstan & 1.001 & 26.4 & 0.97 & 96.1 & 0.91 & 75.1 & 26 & Yes & Yes \\
\hline Kyrgyz Republic & 0.973 & 27.4 & 1.00 & 88.0 & 0.72 & 59.6 & 75 & Yes & Yes \\
\hline Tajikistan & 0.937 & 30.8 & 0.90 & 82.1 & 0.77 & 61.7 & 44 & Yes & Yes \\
\hline Turkmenistan & n.a. & 40.8 & n.a. & n.a. & 0.62 & 49.7 & 61 & n.a. & n.a. \\
\hline Uzbekistan & n.a. & 35.3 & 0.98 & 104.0 & 0.65 & 51 & 36 & No & Yes \\
\hline CCA average & 0.966 & 31.1 & 1 & 94.7 & 0.77 & 60.5 & 42 & & \\
\hline
\end{tabular}

Sources: World Bank, World Development Indicators database, Women, business and the Law (2015); Stotsky et al. (2016); and IMF staff estimates.

Note: Values are for 2013 or latest year available.

$1 /$ The GDI is an index of gender equality, which generally ranges from 0-1, with higher numbers signifying more equality; please see Stotsky et al. (2016) for further details.

2/A higher Gini coefficient implies more inequality.

3/ Data are not available. 
A sizeable gender gap exists in labor force participation in the Middle East and North Africa region and mainly reflects low female labor force participation rates. Studies suggest some possible disincentives for women's participation in the workforce: i) high household incomes may encourage some married women to remain out of or leave the workforce; ii) cultural and religious traditions regarding gender norms; iii) legal prohibitions or limitations; iv) insufficient access to and the quality of education for girls; v) lack of mobility and opportunity in employment and unequal pay for equal work; and vi) lack of parental leave and child care (Elborgh-Woytek, et al., 2013; Goldin, 1994; IMF, 2013; and World Bank, 2013).

The last three columns in Table 1 highlight one indicator of women's health and two indicators of legal rights. The maternal mortality ratio, measured as the number of deaths per 100,000 women, has a considerable range: from 6 in Qatar, which is close to the ratio of 5 in the United States, to 850 in Somalia. According to the World Bank's Women, Business, and the Law dataset, no country in the Middle East and North Africa has adequate legislation on domestic violence against women. ${ }^{7}$ Two countries do not guarantee equal property ownership to marital partners.

Countries in the Caucasus and Central Asia region perform better on education and health indicators of gender equality. Almost all these countries enjoy near parity in gross secondary enrollment rates. At approximately 15 percent, the average gender gap in the labor force participation rate (over the 2000-2011 period) in the Caucasus and Central Asia is among the smallest in the world (IMF, 2013). ${ }^{8}$ This sub-region also has, on average, a relatively low maternal mortality ratio; the regional average is below that for emerging and developing economies as a whole.

\section{Fiscal ConteXt for Gender BUdgeting}

Table 2 offers a snapshot of the fiscal environment in the Middle East and North Africa and Caucasus and Central Asia regions from 2010-2015. While on average, budgets were in surplus in both regions during this time, the picture differs across oil and non-oil exporters. Oil exporting countries in both regions had a budget surplus greater than five percent of GDP, while non-oil exporting countries showed budget deficits. In terms of social spending, oil-exporters tended to spend less on education and health compared to their non-oil exporting counterparts, as a proportion of GDP.

\footnotetext{
${ }^{7}$ In 2015, Algeria passed a law to criminalize domestic violence.

${ }^{8}$ Somach and Rubin (2010) point out in their review of five Central Asian countries that after the end of the Soviet era, women left the labor force because childcare at work and paid maternity leave benefits were reduced.
} 
Table 2. Fiscal Indicators ${ }^{1}$ and Public Expenditure and Financial Accountability (PEFA)

\begin{tabular}{|c|c|c|c|c|c|c|c|c|}
\hline \multicolumn{8}{|c|}{ Average over 2010-2015² (percent of GDP) } & \multirow{2}{*}{$\begin{array}{c}\begin{array}{c}\text { PEFA } \\
\text { (latest year } \\
\text { available) }\end{array} \\
\begin{array}{c}\text { PEFA } \\
\text { overall } \\
\text { score }^{5}\end{array}\end{array}$} \\
\hline Country & $\begin{array}{c}\text { Total } \\
\text { revenue }\end{array}$ & $\begin{array}{l}\text { Total tax } \\
\text { revenue }\end{array}$ & $\begin{array}{c}\text { Total } \\
\text { expenditure }\end{array}$ & $\begin{array}{c}\text { Education } \\
\text { expenditure }\end{array}$ & $\begin{array}{c}\text { Health } \\
\text { expenditure }\end{array}$ & $\begin{array}{l}\text { Overall } \\
\text { balance }\end{array}$ & $\begin{array}{c}\text { Gross }^{4} \\
\text { debt }\end{array}$ & \\
\hline$\overline{\text { Afghanistan }}$ & 23.1 & 8.1 & 23.2 & $1.7^{*}$ & 1.7 & -0.0 & n.a. ${ }^{6}$ & 2.4 \\
\hline Algeria $^{7}$ & 37.9 & 35.7 & 39.3 & $4.3^{*}$ & 4.1 & -1.3 & 10.0 & n.a. \\
\hline Bahrain $^{7}$ & 24.8 & 1.0 & 28.5 & 2.7 & 3.1 & -3.7 & 35.5 & n.a. \\
\hline Djibouti & 33.9 & 19.7 & 36.7 & 4.5 & 5.2 & -2.8 & 45.3 & n.a. \\
\hline Egypt, Arab Rep. & 23.1 & 13.9 & 33.7 & $3.8^{*}$ & 2.0 & -10.7 & 79.4 & n.a. \\
\hline Iran, Islamic Rep ${ }^{7}$ & 17.3 & 5.6 & 16.9 & 3.9 & 2.7 & 0.4 & 13.3 & n.a. \\
\hline $\operatorname{Iraq}^{7}$ & 45.8 & 1.0 & 46.1 & n.a. & 2.8 & -0.3 & 40.3 & n.a. \\
\hline Jordan & 24.6 & 15.4 & 32.8 & $4.9^{*}$ & 5.5 & -8.2 & 76.6 & 2.6 \\
\hline Kuwait $^{7}$ & 71.7 & 0.8 & 39.8 & $3.8^{*}$ & 2.2 & 31.9 & 8.3 & n.a. \\
\hline Lebanon & 21.6 & 15.8 & 29.2 & 2.0 & 3.1 & -7.6 & 134.1 & n.a. \\
\hline Libya $^{7}$ & 60.5 & 2.0 & 55.7 & $2.7^{*}$ & 2.8 & 4.9 & 4.5 & n.a. \\
\hline Mauritania & 26.1 & 15.2 & 25.9 & 4.1 & 1.8 & 0.2 & 75.8 & 2.3 \\
\hline Morocco & 27.5 & 23.0 & 33.3 & 6.4 & 2.1 & -5.8 & 55.3 & 3.0 \\
\hline $\mathrm{Oman}^{7}$ & 47.0 & 2.6 & 41.3 & $4.2^{*}$ & 2.1 & 5.8 & 5.3 & n.a. \\
\hline Qatar $^{7}$ & 44.1 & 6.0 & 31.0 & $2.4^{*}$ & 1.7 & 13.1 & 36.6 & n.a. \\
\hline Saudi Arabia ${ }^{7}$ & 42.2 & 1.2 & 34.1 & $5.1^{*}$ & 2.6 & 8.1 & 4.9 & n.a. \\
\hline Sudan & 14.5 & 6.2 & 15.8 & $2.2^{*}$ & 1.8 & -1.3 & 82.1 & 1.7 \\
\hline Syrian Arab Republic & 20.8 & 12.7 & 28.6 & $4.9^{*}$ & 1.5 & -7.8 & 30.0 & n.a. \\
\hline Tunisia & 24.0 & 20.9 & 27.6 & 6.2 & 4.1 & -3.6 & 43.5 & 3.2 \\
\hline United Arab Emirates ${ }^{7}$ & 38.4 & 23.2 & 31.0 & $1.1^{*}$ & 2.2 & 7.4 & 18.2 & n.a. \\
\hline Yemen, Rep ${ }^{7}$. & 26.3 & 6.5 & 31.8 & $4.6^{*}$ & 1.4 & -5.4 & 45.9 & n.a. \\
\hline MENA average & 33.1 & 11.3 & 32.5 & 4.3 & 2.7 & 0.6 & 42.2 & 2.5 \\
\hline MENA oil exporters & 41.5 & 7.8 & 35.9 & 3.3 & 2.5 & 5.5 & 20.2 & n.a. \\
\hline MENA non-oil exporters & 23.9 & 15.1 & 28.7 & 4.7 & 2.9 & -4.8 & 69.1 & 2.5 \\
\hline
\end{tabular}

(Continue to the next page) 


\begin{tabular}{|c|c|c|c|c|c|c|c|c|}
\hline \multicolumn{8}{|c|}{ Average over 2010-2015 (percent of GDP) } & \multirow{2}{*}{$\begin{array}{c}\text { PEFA } \\
\text { (latest year } \\
\text { available) }\end{array}$} \\
\hline Country & $\begin{array}{c}\text { Total } \\
\text { revenue }\end{array}$ & $\begin{array}{l}\text { Total tax } \\
\text { revenue }\end{array}$ & $\begin{array}{c}\text { Total } \\
\text { expenditure }\end{array}$ & $\begin{array}{c}\text { Education } \\
\text { expenditure }\end{array}$ & $\begin{array}{c}\text { Health } \\
\text { expenditure }\end{array}$ & $\begin{array}{l}\text { Overall }^{3} \\
\text { balance }\end{array}$ & $\begin{array}{c}\text { Gross }^{4} \\
\text { debt }\end{array}$ & \\
\hline$\overline{\text { Armenia }}$ & 21.6 & 17.8 & 24.3 & 3.0 & 1.9 & -2.7 & 36.0 & 3.1 \\
\hline Azerbaijan $^{7}$ & 42.8 & 12.4 & 35.1 & 2.6 & 1.2 & 7.7 & 11.7 & n.a. \\
\hline Georgia & 28.2 & 24.7 & 30.1 & 2.3 & 1.9 & -1.9 & 31.4 & 3.4 \\
\hline Kazakhstan ${ }^{7}$ & 26.0 & 23.5 & 21.7 & $3.1^{*}$ & 2.4 & 4.2 & 11.6 & n.a. \\
\hline Kyrgyz Republic & 33.4 & 19.4 & 38.3 & 6.3 & 3.9 & -4.9 & 51.0 & 2.1 \\
\hline Tajikistan & 25.0 & 17.0 & 26.4 & 4.0 & 1.8 & -1.3 & 33.3 & 2.5 \\
\hline Turkmenistan $^{7}$ & 18.2 & 8.0 & 14.9 & 3.0 & 1.2 & 3.3 & 13.3 & n.a. \\
\hline Uzbekistan $^{7}$ & 38.7 & 20.3 & 33.4 & n.a. & 3.0 & 5.4 & 9.0 & n.a. \\
\hline CCA average & 29.2 & 17.9 & 28.0 & 3.5 & 2.2 & 1.2 & 24.7 & 2.8 \\
\hline CCA oil exporters & 31.4 & 16.0 & 26.3 & 2.8 & 1.9 & 5.2 & 11.4 & n.a. \\
\hline CCA non-oil exporters & 27.1 & 19.7 & 29.8 & 3.9 & 2.4 & -2.7 & 37.9 & 2.8 \\
\hline
\end{tabular}

Sources: World Economic Outlook (WEO), World Bank Development Indicators (WDI) and IMF staff calculations.

Note: A * reflects value of latest year available since data were not available for the 2010-2013 period. Afghanistan (1982), Algeria (2008), Egypt (2008), Jordan (1999), Kuwait (2006), Libya (1999), Oman (2009), Qatar (2008), Saudi Arabia (2008), Sudan (2009), Syria (2007), UAE (1997), Yemen (2008), and Kazakhstan (2009).

$1 /$ All figures except for health and education expenditure are drawn from the latest WEO and concept of government corresponds to that in the WEO. Please see WEO for further details. Health and education expenditure are drawn from the World Bank Development Indicators (WDI) and correspond to the general government concept.

$2 /$ This is the average over the number of years in this period for which data were available.

3/ This corresponds to the concept of total revenue minus total expenditure.

4/ Gross debt does not net out holdings of debt by other entities of the government.

5/ PEFA is a performance monitoring framework used to assess the public financial management systems in developing countries. It is an initiative jointly supported by the World Bank, IMF, European Commission, and other development and government institutions. The framework consists of 28 indicators with each indicator scored on a scale from A (highest) to D (lowest). PEFA scores reported above are an average of the 28 indicators and convert the four ordinal PEFA scores (A, B, C, D) to numerical scores $(4,3,2,1)$ with " + " score given 0.5 point. A higher PEFA score implies stronger administration of public finance. On a global basis, the lowest score is 1.1 and highest score is 3.6. Please see https://www.pefa.org/ for further details.

6/ Data are not available.

7/ Italicized countries are oil exporters 
Fiscal policies can play an important role in promoting gender equality and women's development. Government budgets may have differential effects on men and women (Elson, 2002; Stotsky, forthcoming). As part of a well-designed gender budgeting initiative, governments should analyze how their policies can promote gender equality and women's development, and then integrate these ideas into the laws, regulations, and practices governing the budget (see Box 1 for further discussion). Originating in Australia in the mid-1980s, gender budgeting spread to South Africa and beyond by the mid-1990s and has now been implemented with varying objectives and intensity in around 80 countries. Gender budgeting has been used to increase access to education, childcare, and health services; promote higher rates of female labor force participation; and reduce violence against women. These initiatives have received support from a number of multinational organizations, including UN Women, the Commonwealth Secretariat, the European Community, and the World Bank, and by civil society institutions and bilateral donors. The Commonwealth Secretariat sponsored some of the earliest pilot projects in gender budgeting, and in recent years, UN Women has taken a leading role in supporting the expansion of gender budgeting globally (UN Women, 2009).

\section{Box 1: What is Gender Budgeting?}

Gender budgeting, also referred to as gender sensitive budgeting or gender responsive budgeting, is an approach to budgeting fiscal authorities can use to address gender inequality and the advancement of women, in areas such as education, health and economic empowerment (Budlender and Hewitt,2003; Budlender and Sharp, 1998; Elson, 2003; and Stotsky, 2006). If well designed, gender budgeting can improve the efficiency and equity of the overall budget process. The fiscal authorities at any level of government can assess the needs of men and women; identify key outcomes or goals; plan, allocate, and distribute public funds; and monitor and evaluate achievements. While gender budgeting initiatives around the world have tended to focus on expenditure policies, revenue policies can also influence gender equality and should therefore be considered part of gender budgeting. Stotsky (forthcoming) points out that gender budgeting should integrate all gender-related concerns, including those of men and boys, into fiscal policies and management.

\section{Effective Gender Budgeting Initiatives in the Middle East and Central Asia REGION}

In this section, we summarize gender budgeting efforts in Morocco and Afghanistan. We also analyze the relationship between gender budgeting and indicators of gender equality and the advancement of women comparing each country to its regional counterparts. Appendix B provides a summary, in table form, of the origins, fiscal policy components, legal basis, and roles of government and civil society in the gender budgeting programs of Morocco, Afghanistan, and Egypt. 


\section{A. Morocco}

\section{Origins of gender budgeting}

Morocco is notable for having the first and most developed gender budgeting initiative in the region. The country started its initiative in 2002, when the Ministry of Finance and Privatization took the first steps, with the support of the World Bank, by conducting preliminary research on the "methodological feasibility of budgetary accounts for gender and childhood in Morocco" (Chafiki and Touimi-Benjelloun, 2007). ${ }^{9}$ One of Morocco's goals was to improve its performance in meeting the Millennium Development Goals, and early efforts focused on adapting sectoral budgets for the Ministries of Education and Training, Health, and Agriculture and Rural Development to address these goals (UN Women, 2007). There was also an emphasis on increasing women's public employment and collecting sex-disaggregated data.

The Ministry of Economy and Finance published the inaugural Gender Report in 2006, which covered four ministries, each of which identified key areas where gender gaps existed, offered assessments, and set goals for future performance. Successive reports followed a similar outline, and the number of ministries, departments or agencies included in this report expanded each year, reaching 31 by 2016 and covering 80 percent of the federal budget. The Gender Report was initially designed to be an annex to the Economic and Financial Report, but became a standalone document that accompanies the annual Finance Bill presented to parliament.

The Gender Report has become a cornerstone of Morocco's gender budgeting initiative, and highlights key priorities and targets for the various ministries, along with accomplishments. The report has evolved over time. The earliest versions, from 2005-2007, included gender-based analysis of government policies and programs. The 2008 version examined performance indicators for operating and capital budgets. Subsequent Reports added an evaluation of measurable indicators of human rights.

Some ministries report sectoral- and sex-disaggregated data such as a breakdown of staff by sex or expenditures on women's programs. For example, in the 2008 Gender Report, the Ministry of Justice discusses the evolution of increased gender equality in family, penal, and nationality laws. It also notes that while women's representation in the magistrate system has increased, it still remains well below the goal of one-third set by the Ministry of Justice. The Report highlights how the Ministry of Justice created a "Gender Unit" and offers a brief analysis of gender-sensitive goals in the operating budget. In the latest Gender Report, summary tables provide a breakdown of the share of women employed in each department as well as information

\footnotetext{
${ }^{9}$ Morocco's initiative was also part of UNIFEM's Global Gender Responsive Budgeting Program, which was in effect between 2002 and 2008. During this time, Morocco mainly stressed relationship-building and training for technical staff on topics covering literacy, vocational training, health, and employment, and developed a manual for gender budgeting in 2005 (UN Women, 2009).
} 
on what percentage of women are in management positions. Descriptions of the existence and organization of the gender unit in each department are also available. The Report serves as "an important accountability and monitoring tool, advancing implementation of [gender responsive budgeting] from one year to the next" (UN Women, 2014a).

Motivations, goals, and foci

Morocco linked its gender budgeting initiative to its national development strategy. The Government Plan for Equality for 2012-2016, which followed the 2006 National Strategy for Gender Equality, included 143 measures aimed at improving gender equality in education, health, and labor market opportunities, and increasing social, political, and economic empowerment. ${ }^{10}$ The Plan's key goals mirror several Millennium Development Goals, such as eliminating all discrimination and violence against women and providing equal access to health and education services and decision-making positions. As an example, Objective 5 focuses on enacting laws to protect women and combat discrimination. In 2014, the Moroccan parliament voted unanimously to amend Article 475 of the penal code, which previously allowed accused rapists to avoid prosecution by marrying the victim. Objective 9 addresses girls' access to education at all levels, and Morocco has eight ministries involved in achieving this goal.

Morocco continues to work with international organizations to strengthen its gender budgeting efforts. In 2013, UN Women established one of three Gender Responsive Budgeting Centers for Excellence in Morocco (in addition to Russia in 2012 and Mozambique in 2011) (UN Women, 2014b). The Centers conduct research on gender budgeting initiatives and offer knowledge sharing and training for stakeholders, including government officials, civil servants, and civil society members. The Moroccan Center is based in the Ministry of Economy and Finance.

\section{Legal framework for gender budgeting}

Morocco has also taken steps to enshrine gender equality in its legal framework. The 2003 Labor Code mandates equal remuneration for equal work (Sadiqi, 2010), and there are legal provisions banning discrimination in hiring (World Bank, 2015a). Women are guaranteed maternity leave and fathers, three days of paternity leave. Sadiqi (2010) notes that nursing mothers must be provided with a one-hour break each workday. No penalty may be imposed upon mothers returning from maternity leave.

The 2004 Moudawana (family code) included specific provisions designed to improve gender equality and the status of women. The first fundamental reform stated that "women are men's sisters before the law." Other pillars addressed women's rights to divorce, self-guardianship, and child custody, and introduced penalties for sexual harassment; however, polygamy and

\footnotetext{
${ }^{10}$ Out of the 45 million euro budget for the plan, which represents about 0.3 percent of the 2011 fiscal year budget for the Ministry of Economy and Finance, approximately 83 percent was devoted to budget support and 17 percent to technical assistance activities, including education, training, monitoring, and evaluation and audit (Ministry of Economy and Finance of Morocco, 2013).
} 
inequalities in inheritance rules remained legal (Freedom House, 2010). World Bank (2015c) points out that despite these changes, limited implementation and enforcement of laws, combined with weak institutional capacity and social norms, hinder women's advancement.

The Nationality Code was reformed in 2007 to permit children to inherit Moroccan citizenship from their mothers. In 2011, a new constitution was approved by a majority of voters. Article 19 guarantees that " $[\mathrm{t}] \mathrm{h}$ man and the woman enjoy, in equality, the rights and freedoms of civil, political, economic, social, cultural and environmental character" and that " $[\mathrm{t}]$ he State works for the realization of parity between men and women." Article 30 ensures both men and women have equal rights to vote, while Article 34 outlines the government's responsibility "to respond to and provide for the vulnerability of certain categories of women and of mothers, of children, and of elderly persons" (Constitute Project, 2012). To further encourage gender equality, in 2011 the government established a quota of 15 percent for female representation in parliament and 33 percent for female representation in local government.

The Council of Government approved an organic finance law with two key components designed to strengthen gender budgeting in 2014. First, the law requires that gender equality be considered when defining performance objectives, results, and indicators in all line budgets. Second, the law dictates that the Gender Report be included as part of each year's Finance Bill (UN Women, 2014c). The latest Government Plan for Equality calls for strengthening this law by increasing transparency, improving fiscal performance, and generalizing evaluation, audit, and accountability procedures (Ministry of Economy and Finance of Morocco, 2013). These efforts were recognized by the international community with the Ministry of Economy and Finance receiving the United Nations Public Service Award in 2014.

\section{Sex-disaggregated data}

Morocco's gender budgeting effort incudes data collection. The Ministry of Economy and Finance carried out a survey to collect sex-disaggregated data, focused mostly on education, employment and health outcomes, to better understand local development needs of women and men (UN Women, 2007), and posted the data on Manar ${ }^{11}$ (Survey response). In 2007, the Ministry, in cooperation with UN Women, conducted a comprehensive review of gender-related statistics. The High Commission for Planning administered a time-use survey in 2012 to understand the daily household activities of women, men, and children. The High Commission for Planning publishes statistics, "Moroccan Women in Figures," on National Women's Day.

Assessment, monitoring, and evaluation

Morocco's first efforts at gender budgeting were summarized in a 2005 report from a joint partnership of UNIFEM, the European Union, Association Démocratique des Femmes du Maroc,

\footnotetext{
${ }^{11}$ Manar can be accessed at: http://manar.finances.gov.ma/manar/initAccueilInscription
} 
and UNICEF. The report covered five separate local gender budgeting programs in urban and rural Morocco and noted "the existence of a genuine political desire and the willingness of many strategic stakeholders to apply equity in the repartition of local resources." Despite this political will, the authors pointed out that gender budgeting in Morocco still had a long way to go to reach its objectives. One crucial feature missing from Morocco's gender budgeting efforts was a process for monitoring and evaluation. Other suggested improvements included greater participation from stakeholders, capacity building for women's organizations, and improved transparency during the local budgeting process.

\section{Revenue}

As the World Bank's report on Women, Business, and the Law 2016 notes, 16 out of 173 countries have a tax system that directly favors men, and Morocco is one of these countries (El Bouazzaoui et al., 2010). There are both explicit and implicit gender biases in Morocco's taxation system. The direct bias relates to Article 74, which provides a dependent deduction for men but not for women. That is, a male taxpayer may claim a deduction for his wife and dependent children, but unless a wife is able to prove legally that her husband and children are dependent on her, she may not claim a similar deduction. ${ }^{12}$ In addition, as El Bouazzaoui et al. point out, an implicit bias is that there are no deductions for child care, which might hinder women's ability to fully participate in the workforce.

\section{Implications of gender budgeting initiatives in Morocco through trends analysis of key indicators}

To try to assess the relationship between gender budgeting and indicators of gender equality and the advancement of women, we compare the performance of Morocco to its regional counterparts. Additionally, we look at the relationship between gender budgeting and two indices that capture the overall level of gender inequality in a country. In view of Morocco's emphasis in its initiative on raising girls' and women's human capital, we focus on Morocco's performance in education, health, and labor force participation outcomes (see Box 2 for a discussion on economic growth and gender inequality in education and labor force participation in the region). ${ }^{13}$ We compare Morocco's performance between 1995 and 2013 to other non-oil exporting, Middle East and North Africa emerging markets to track its transition since the pre-

\footnotetext{
12 This effectively means that although the benefit is not automatic, it is possible when a woman is a legal guardian. At issue is whether it is cumbersome for a household to give legal guardianship to a woman.

${ }^{13}$ While gender budgeting is one tool that can be used to reduce gender inequality, we note that it is certainly not the only option governments have at their disposal. Gaps in education enrollment rates for example, may not be remedied solely through increased spending, particularly in advanced or emerging markets. Increasing female enrollment may require a combination of social, legal, and institutional changes coupled with targeted, efficient government spending. Laframboise and Trumbic (2003) study the impact of social public expenditure on women's economic development in Middle East and North Africa and find a weak correlation between the level of government spending on education (health) and female education (health) indicators, but this relationship disappears after controlling for income and maternal literacy rates. They conclude that rather than the level of government spending, it is the efficiency of social expenditure that is key to promoting women's economic advancement in the region (Laframboise and Trumbic, 2003).
} 
gender budgeting period. As can be seen in Figure 2, Morocco lags its counterparts in many of the performance indicators. The ratios of female-to-male gross secondary and gross tertiary enrollment rates increased in both Morocco and the comparison group, yet Morocco remains behind its counterparts by 12 points for gross secondary and 30 points for gross tertiary enrollment (Figure 2a). Morocco and its regional counterparts halved their rates of maternal mortality from 1995 to 2013, but overall, Morocco's ratio of maternal mortality remained higher than that of other non-oil exporting Middle East and North Africa emerging markets (Figure 2b). The female labor force participation rate decreased from 1995 to 2013 in Morocco but increased in the comparison group, so that by 2013, the rates in the two were almost equal (Figure 2c). A similar story of convergence emerges when looking at the ratio of female-to-male labor force participation rates: Morocco's ratio remained virtually unchanged over the two decades, while the average ratio for other non-oil exporters in the region increased.

Using two indexes, the GDI and GII, to measure the overall level of gender inequality, both the comparison group and Morocco show improvement, yet the overall level of inequality in Morocco remains higher under both measures. One positive development is the improvement in the ratio of female-to-male net primary enrollment. Morocco was well behind its regional counterparts in 1995, but by 2013, it pulled ahead and achieved near parity between female and male primary school enrollment.

We now turn our attention to the data included in Morocco's 2016 Gender Report, ${ }^{14}$ which offers data disaggregated by gender and by rural/urban areas on education, employment, and health outcomes (among others). This allows for additional insight into the progress Morocco has made over a ten-year period, although we are not able to offer a cross-country comparison due to lack of similar data for peer countries. Figure 3 shows the enrollment rates in primary and secondary school and illiteracy rates. Similar to the results shown in Figure 2a, we see that there is almost complete parity in primary school enrollment rates regardless of gender or location. In ten years, Morocco has been able to increase its primary enrollment rate for girls in rural areas by more than 18 percentage points, thereby achieving parity between genders and between regions.

The gaps between urban and rural regions and males and females are more pronounced for the 12-14 year olds and 15-17 year olds, although again, enrollment rates have increased over time. Urban 12-14 year-old females have largely closed the gap with urban 12-14 year-old males, but 15-17 year-old urban females remain 10 percentage points behind urban males. When we look at the rural enrollment rates though, we notice some striking differences. Females aged 12-14 in rural areas have an enrollment rate that is 12 percentage points lower than males aged 12-14 in rural areas and more than 32 percentage points lower than females aged 12-14 in urban areas.

\footnotetext{
${ }^{14}$ We thank Zineb Bouba at the Moroccan Ministry of Economy and Finance for providing us with the 2016 Gender Report.
} 
Enrollment rates for both males and females aged 15-17 in rural areas are below 50 percent, and there is a 20 percentage point gender gap for these two cohorts. But both males and females in rural regions in this age group are well behind their urban counterparts.

Illiteracy rates have shown improvement over the last ten years; however, there remains a sizeable gender gap (almost 17 percentage points) between males living in urban areas and females living in urban areas. Males living in rural areas lag females living in urban areas though. The illiteracy rate for females residing in rural areas has dropped from almost 90 percent to 60 percent, but this rate is still double that of females in urban areas.

The Gender Report also provides data on the proportion of assisted deliveries by qualified personnel. By 2011, qualified personnel were present at more than half of assisted deliveries in rural areas; this is a gain of more than 28 percentage points over the rate in 2002, the year when gender budgeting was initiated in Morocco. In urban areas, more than 92 percent of assisted deliveries had qualified personnel present, up from 75 percent in 2002.

\section{Box 2: Evidence on Gender Inequality and Growth in Middle East and Central Asia}

We summarize some of the studies assessing the relationship between gender inequality and economic growth in Middle East and Central Asia. Their findings support the idea that reducing gender inequality and addressing women's needs in education, health, and employment outside the home would increase women's productivity and improve economic growth.

- Klasen and Lamanna (2009) investigate the effect of education and employment gaps on growth, using a panel dataset that includes Middle Eastern countries and find that genderrelated education and employment gaps have a negative impact on growth.

- Woetzel et al. (2015) assess the effect that equalizing the labor supply between men and women has on economic output. Closing this gap in the Middle East and North Africa would raise output by 47 percent, and in Eastern Europe and Central Asia by 23 percent by 2025 compared to a business-as-usual estimate. However, one limitations, which is likely to lend a significant upward bias, is that that analysis focuses only on the supply of labor.

- Cuberes and Teignier (2014) develop a theoretical model to examine how gender gaps in entrepreneurship and labor force participation impact aggregate income and productivity. They model gender discrimination in the form of limits on women's opportunities and wages in labor markets. Using country-specific parameters, they find that gender inequality in the labor market can lead to a total income loss of 27 percent in the Middle East and North Africa, where women's labor force participation remains low.

- Cavalcanti and Tavares (2016) calculate output losses due to gender discrimination in the labor force. Using the United States as the baseline country, the authors find that if the US were to have gender wage gaps similar to those in Egypt or Saudi Arabia, output in the US would only be 42 percent of its current level. 
Figure 2. Trends in Gender Inequality in Morocco and its Regional Counterparts

\section{2a. Educational Enrollment ${\text { (female to male ratio })^{1 /}}^{1 /}$}

Morocco remains behind its counterparts in the ratio of gross secondary enrollment and gross tertiary enrollment of girls to boys. It has achieved gender parity in primary enrollment.

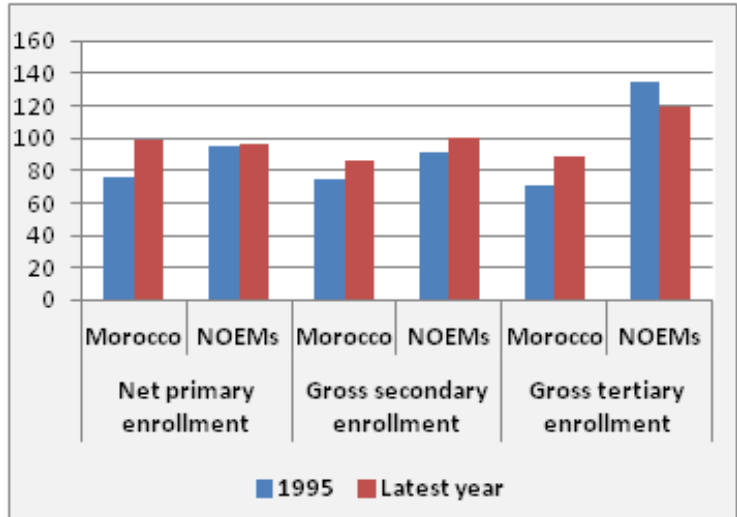

2c. Labor Force Participation (ages 15 - 64)

The female labor force participation rate declined while the female to male ratio remained unchanged.

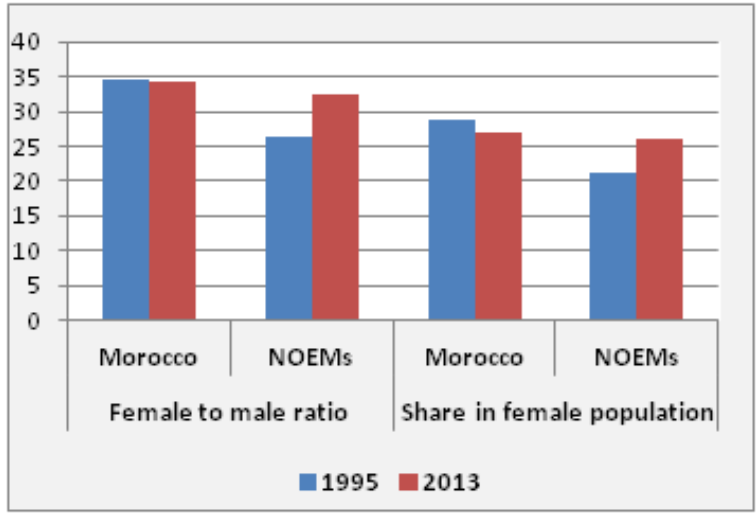

\section{2b. Maternal Mortality Ratio} (modeled estimate, per 100,000 live births)

Morocco's rate of maternal mortality remained higher than that of other NOEMs, ${ }^{2}$ but it has made substantial progress over 20 years.

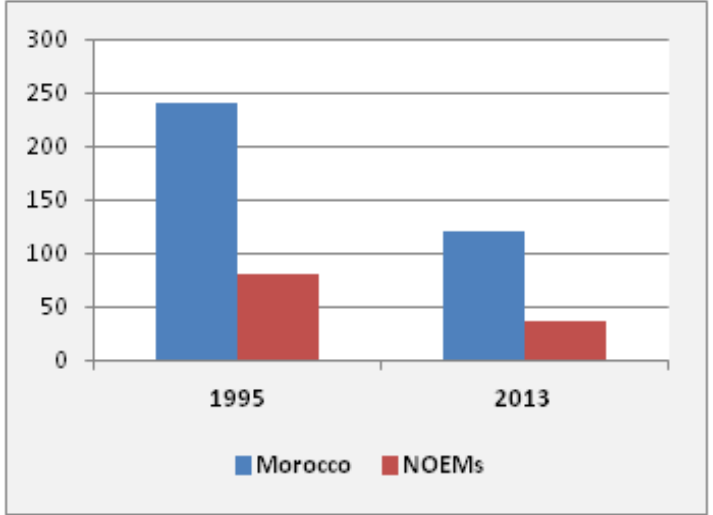

2d. Gender Inequality Indices ${ }^{3 /}$

The overall level of inequality in Morocco remains higher than in its counterparts.

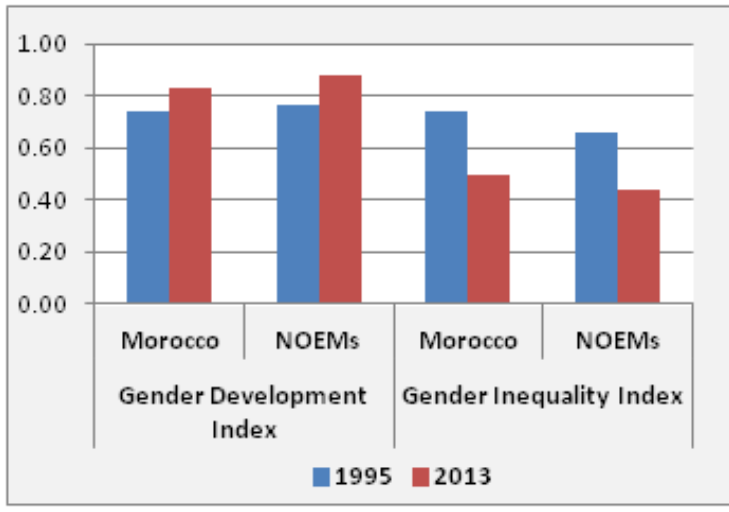

Sources: World Bank, World Development Indicators; Stotsky et al. (2016); IMF staff estimates

${ }^{1 /}$ The data for net primary enrollment and gross secondary enrollment are for 2012 and gross tertiary enrollment, 2010. The average for comparator countries for the tertiary level excludes Qatar, an outlier.

${ }^{2 /}$ NOEMs stands for non-oil exporting emerging markets in the Middle East and North Africa which consists of Algeria, Bahrain, Iran, Iraq, Kuwait, Libya, Oman, Qatar, Saudi Arabia, and the United Arab Emirates. 3/ A higher value on the GDI represents more gender equality while a lower value on the GII represents more equality. 


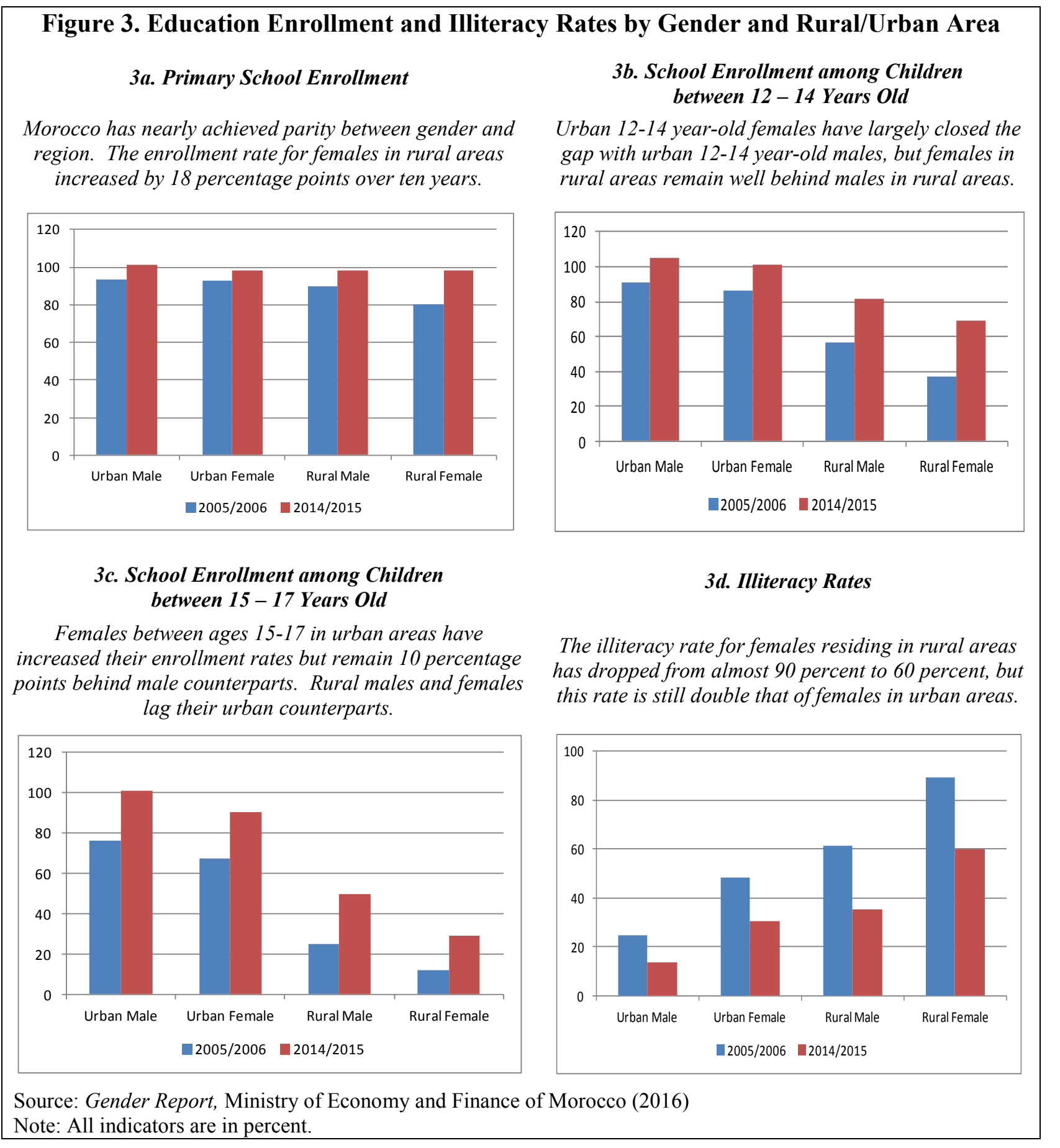




\section{B. Afghanistan}

\section{Origin of Afghanistan's gender budgeting initiative}

Afghanistan has confronted many economic problems in recent years, and Afghan women still face great challenges in achieving equal rights and gender equity. Afghanistan's gender budgeting effort started in 2005 with the support of the German Agency for Technical Cooperation (Alvi, 2011; Reinhard, 2010). One of the government's first steps was to establish the Gender Budgeting Working Group in the Ministry of Finance. Afghanistan's gender budgeting initiative's pilot program, led by the Ministry of Finance and Ministry of Women's Affairs, targeted the Ministries of Education; Public Health; Higher Education; Agriculture, Irrigation, and Livestock; Rural Rehabilitation and Development; and Women's Affairs (Reinhard, 2010; Shah, 2010; Afghanistan Ministry of Finance, 2014). Since 2008, government officials in the pilot ministries have received training in gender budgeting from multiple civil society and international organizations, including Counterpart International, Equality for Peace and Development, and the UNDP.

\section{Gender budgeting goals}

The 2010 National Budget was the first to incorporate gender budgeting, and stated that the government is "firmly committed to equitable distribution of the benefits of national development among men and women" (Afghanistan Ministry of Finance, 2009, p. 39). It also stipulated that gender-related goals, for both males and females, in the Afghanistan National Development Strategy, are to be achieved through the gender budgeting initiative. Several of these goals are in line with the Millennium Development Goals (Afghanistan Ministry of Women's Affairs, 2005). ${ }^{15}$

As part of the gender budgeting initiative, the Afghan government collected data on eight key areas to monitor progress on the Millennium Development Goals: i) net enrollment in primary education; ii) proportion of pupils who started grade one and reach the last grade of primary school; iii) literacy rate of women and men between ages 15 and 24; iv) ratios of girls to boys in primary, secondary, and tertiary education; v) share of women in wage employment in the nonagricultural sector; vi) proportion of seats held by females in the national parliament; vii) maternal mortality ratio; and viii) proportion of births attended by skilled health personnel. The National Action Plan for the Women of Afghanistan assigned responsibility for collecting data and preparing reports to each relevant ministry and designated the Ministry of Women's Affairs as the central organizer.

\footnotetext{
${ }^{15}$ Although these goals are now superseded by the Sustainable Development Goals, they remain relevant insofar as they provided targets, and thus evidence on the country's performance so far in achieving gender equality.
} 
Regarding spending goals, the Ministry of Finance, upon the establishment of the gender budgeting unit in 2007, committed to spend US\$5 million, a minimal portion of the total budget in the 2009 budget year, to meet "the most pressing needs within the area of gender that would otherwise not have been covered by the usual budgetary allowances (Reinhard, 2010, p. 4)."16 The National Action Plan for the Women of Afghanistan also encouraged all ministries to spend no less than 30 percent of their development and operations budget for policies, programs, and activities for women's advancement (Afghanistan Ministry of Women's Affairs, 2005).

Afghanistan's gender budgeting initiative also sought to increase female public employees in each pilot ministry. For instance, the 2014 National Budget Statement provides a hiring goal for the female share of employees. Unfortunately, it is unclear how strictly these goals are enforced or whether each pilot ministry and/or the Ministry of Finance tracks them.

\section{Legal basis for gender budgeting and other gender-related laws}

Afghanistan's Public Finance and Expenditure Management law is meant to improve the accountability and effectiveness of its budgeting process; however, gender budgeting does not seem to be defined within this law (Rade, Thiessen, and Huber, 2014). The country has other laws to protect women's rights including laws on marriage, education, public health, and the elimination of all violence against women (Afghanistan Research and Evaluation Unit, 2013). Additionally, the 2004 Constitution guarantees women equal status mandates a quota of 20 percent for female representation in both the lower and upper houses of the Parliament (Afghanistan Research and Evaluation Unit, 2013).

\section{Governmental and non-governmental actors involved}

Civil society and international organizations, such as the Deutsche Gesellschaft fur Technische Zusammenarbeit, Equality for Peace and Democracy, UN Women and UNDP, have worked with the Ministry of Finance to further develop gender budgeting. In addition to receiving training on gender budgeting from such organizations, the Ministry of Finance has held workshops with civil society organizations to promote accountability and transparency in the public sector and to train civil society organizations in budget planning, implementation, and monitoring (Equality for Peace and Democracy, 2014).

\section{Reporting on gender budgeting}

The 2015 national budget includes monitoring and assessing the impacts of the gender budgeting initiative, but it does not specify how the evaluation is to be disseminated to the public. It is

\footnotetext{
${ }^{16}$ The Ministry of Finance's total operating budget in 2008 was approximately US\$ 672 million (http://www.budgetmof.gov.af/images/stories/DGB/BPRD/BPU/1387/1387_National_Budget_ENG.pdf, page 42).
} 
evident that the government recognizes the need for collecting sex-disaggregated data, not only to monitor and evaluate programs but also to properly understand gender inequality and reflect it in policies (Afghanistan Ministry of Women's Affairs, 2005; Afghanistan Ministry of Finance, 2015). Nonetheless, no document clearly indicates how such data collection should be conducted.

\section{Implications of gender budgeting initiatives in Afghanistan through trends analysis of key indicators}

Similar to our analysis for Morocco, in Figure 4, we examine education, health, labor force participation, and gender inequality index outcomes in Afghanistan compared to regional counterparts. One of the goals of the Afghanistan National Development Strategy was to increase the net primary enrollment rates to at least 60 percent for boys and 75 percent for girls. In recent years, there was an increase in the ratios of female to male gross primary and gross secondary enrollment in Afghanistan, but as can be seen in Figure 4a, Afghanistan has not caught up to other non-oil exporting low-income developing countries in the region.

Afghanistan set health goals in its gender budgeting initiative, such as providing basic health services to at least 90 percent of the population. While we do not have data to measure this objective directly, we can look at the maternal mortality ratio as a measure of improvements in healthcare. The maternal mortality ratio remains much higher than other non-oil exporting, lowincome developing countries in the region, but Afghanistan did record a sizeable decrease in maternal mortality from 2000 to 2013 (Figure 4b).

Afghanistan planned to train a sizeable number of men and women in marketable skills, and increase the employment rate for chronically poor female-headed households by 20 percent. Figure $4 \mathrm{c}$ shows that there was a slight improvement in both the female and the ratio of female to male labor force participation from 1995 to 2013 in Afghanistan. For the other low-income and developing countries in the Middle East and North Africa as a whole, there was a slight increase in both female and the ratio of female to male labor force participation from 1995 to 2013, but in 2013, Afghanistan remained behind its counterparts.

Finally, Figure 4d considers two overall indicators of gender inequality, the GDI and the GII. Afghanistan has made progress over time in reducing gender inequality according to both measures. However, when put side by side with the averages for low-income and developing countries in the Middle East and North Africa, we see that Afghanistan remains behind its counterparts. The conflict in Afghanistan may be one factor limiting Afghanistan's performance. 
Figure 4. Trends in Gender Inequality in Afghanistan and its Regional Counterparts

\section{4a. Educational Enrollment (in female to male ratio) $)^{1 /}$}

Afghanistan has not caught up to its counterparts, but has made progress in all three indicators. ${ }^{2}$

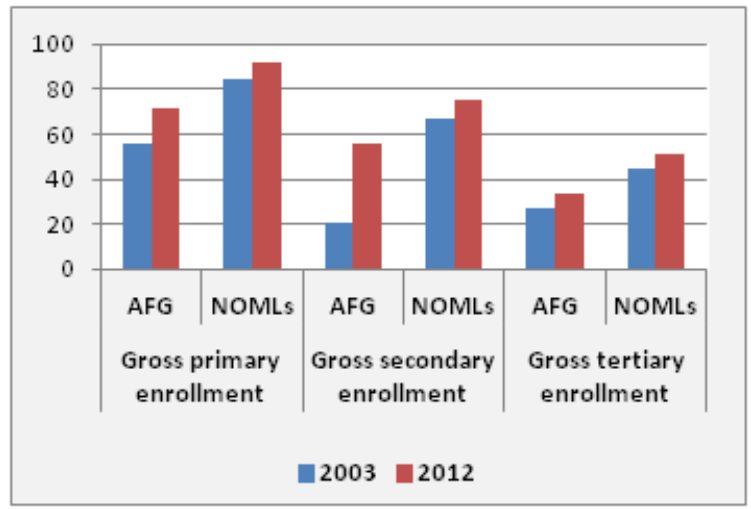

4c. Labor Force Participation (ages 15 - 64)

Afghanistan remains well behind its regional counterparts the female and the ratio of female to male labor force participation.

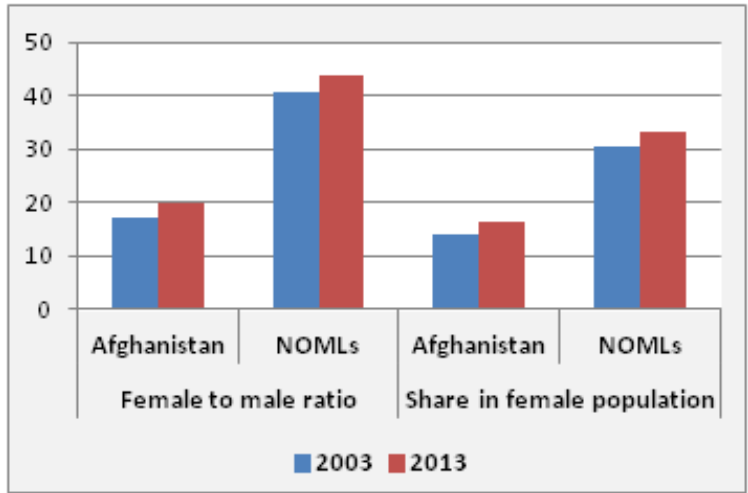

4b. Maternal Mortality Ratio (modeled estimate, per 100,000 live births)

Afghanistan recorded a sizeable decrease in maternal mortality from 2000 to 2013.

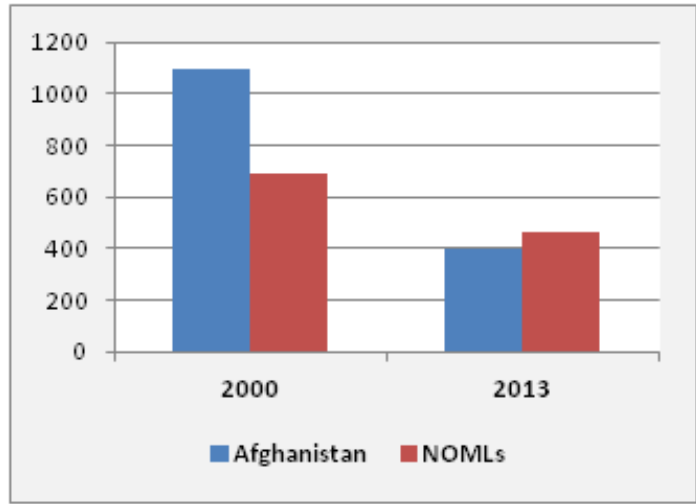

4d. Gender Inequality Indices

Afghanistan has closed some of the gap with its counterparts as measured by the GDI.

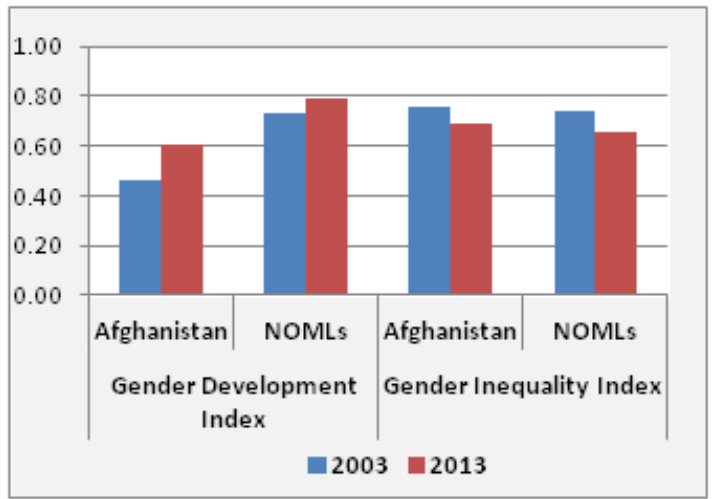

Sources: World Bank, World Development Indicators; Stotsky et al. (2016); and IMF staff estimates.

${ }^{1 /}$ Gross secondary enrollment (2004) and gross tertiary enrollment (2011). AFG stands for Afghanistan.

2/ NOMLs stands for non-oil exporting low-income developing countries in Middle East and North Africa which consists of Djibouti, Mauritania, Somalia, and Sudan. 


\section{Other Gender-Related Initiatives in the Middle East and Central Asia}

In this section, we discuss other gender budgeting or fiscal policy initiatives in the region, designed to address gender inequality and women's advancement.

\section{Egypt}

\section{Origin of Egypt's gender budgeting initiative}

In 2005, the Egyptian government enacted Law 87, which states that the budgeting process should transition from line-item budgeting to performance-based budgeting (Khatab and AlShiekh, 2010). Also in 2005, the National Council for Women, in cooperation with the Ministry of Finance, established the Equal Opportunity Unit within the Ministry of Finance. The Equal Opportunity Unit serves as the link between the National Council for Women and the Ministry of Finance and is tasked with promoting gender equality and monitoring its progress in the workplace as well as eliminating discrimination against women.

The Equal Opportunity Unit, with technical and financial assistance from UNIFEM (now UN Women) and the Embassy of the Netherlands, launched a pilot project to promote equal opportunities for women in the national budget process. The program had two foci: develop a gender responsive budget program and train government personnel to help them understand gender relations and perspectives (OECD, 2010).

The 2008/09 fiscal year marked the beginning of the institutionalization of gender budgeting, as the draft budget circular stated that budgets should reflect the needs of all members of the Egyptian family - men, women, and children - to ensure social equality. In 2009/10 fiscal year, the budget circular instructed ministries and other government bodies to prepare performancebased budgets and to provide sex-disaggregated budget data analyses (Al-Bana, 2010). Furthermore, the 2009/2010 budget law added protection for gender-specific expenditures, as Article 11 of the law requires all entities in the national budget commit to any expenditure relating to social justice or safeguarding children's rights in a way that promotes the application of gender responsive budgets. It also prohibited transferring funds allocated to gender-related items to other budget items without official permission from the Minister of Finance (Egypt Ministry of Finance, 2009). Gender budgeting continued through the 2010/11 fiscal year, when Egypt implemented its first gender responsive performance-based budget (OECD, 2010). However, since that time, the status of Egypt's gender budgeting initiative is unclear.

\section{Motivations, goals and foci}

The initiative's main objective was to promote social justice through equal distribution of public expenditures (OECD, 2010). The program selected target sectors in education, health, labor, social security, youth and social development, housing, food, and infrastructure, and chose 15 governorates to implement a gender budgeting pilot project (OECD, 2010). The initiative was also placed within the five-year national plan and the Millennium Development Goals context; 
therefore, it was expected to contribute to achieving the gender-related national development goals (Budgetary and Human Rights Observatory, 2009).

Some ministries had additional quantitative goals. For instance, the Ministry of Youth was assigned a goal to allocate 40 percent of its entire budget toward making the operation of its youth programs more women-friendly and included the following goals: (i) increase female participation in social programs and volunteers for female youth related programs; (ii) increase female beneficiaries of youth programs; (iii) eradicate illiteracy and enhance general education programs; (iv) train and improve marketable skills; and (v) support women working at youth centers with on-site day care (Budgetary and Human Rights Observatory, 2009).

\section{Gender-related data collection and reporting on gender budgeting}

Egypt's gender budgeting initiative recognized the importance of determining expenditure allocations by sex and age. To conduct this analysis, the Ministry of Finance, working with the Central Agency for Public Mobilization and Statistics, developed gender indicators, collected sex-disaggregated data on beneficiaries of public services within five governorates, and published the data in the Ministry's 2009/2009 statistical statement (OECD, 2010). The data portal offers some gender indicators, with a limited selection of more detailed sex-disaggregated data presented in the Central Agency for Public Mobilization and Statistics' statistical yearbook. For example, the 2015 statistical yearbook shows sex-disaggregated data such as public spending for micro-lending and the female and male shares of managerial positions by rank (Central Agency for Public Mobilization and Statistics, 2015). Auditing was to be another important component of the initiative; gender-based situational analysis was to be updated every two years, and budget analysis was to be conducted every fiscal year. However, these analyses were only done between 2002 and 2007, and the results of the analyses do not appear to be publically available.

\section{Legal basis for gender budgeting and other gender-related laws}

Gender budgeting is not codified or defined in the budget law. In terms of other gender-related laws, Article 40 of the Constitution guarantees equal rights to all citizens and prohibits discrimination based on gender, origin, language and belief (Somach and Rubin, 2010).

\section{Role of the Egyptian government}

The Ministry of Finance had taken a leadership role in implementing gender budgeting in Egypt through the Equal Opportunity Unit. Other ministries involved included the Ministries of Economic Development, Health, Education, Social Security and Social Welfare, Labor, and Family and Housing (Al-Bana, 2010). The initiative also involved other government bodies such as the Central Statistics Agency, the National Council for Women, the Social Development Fund, the Youth High Council, and the Sports High Council (Al-Bana, 2010). 


\section{Armenia}

The Economic Development and Research Center, a domestic non-governmental organization, had a gender budgeting initiative supported by UNIFEM in 2009 that only lasted for a year (Harutyunyan, 2011; Economic Development and Research Center, 2010). This short-term initiative focused mostly on capacity building within the government and civil society. The main results of this project include achieving the endorsement of the project from the Armenian Government, setting a basis for monitoring and evaluating the project, and publishing a report, Gender Responsive Budgeting and Gender State in Armenia (Harutyunyan, 2011). The report provides an analysis of the current state of gender issues in the country in detail and explains gender budgeting in the Armenian context. It is interesting that the report provides a scoring system for how gender-sensitive government ministries are as it is a unique way to evaluate and keep track of the progress of each ministry. The scoring system rates expenditures as gender blind or not possible to determine gender orientation (0), direct or indirect gender orientation (1), and strong gender orientation (2). Programs rated as a " 2 " amounted to 1.4 percent of the total budget expenditure, and most were health-focused. The report notes that " $[\mathrm{t}]$ here is a lack of gender sensitive indicators and provided information is insufficient to get [a] real evaluation of [the] situation" (p.72). It is not clear if this initiative has been extended and continued.

\section{Bahrain}

The official introduction of gender budgeting happened sometime around 2010: an account shows, for example, that 25 million Bahraini dinars was designated in the national budget for the national recruitment and training program for 103 males and 231 females (Government of Bahrain, 2004). The Ministry of Finance of Bahrain introduced gender budgeting in its budget circular for fiscal years 2011 and 2012, which encouraged ministries and agencies to conduct gender analysis of expenditure (Esim, 2011).

\section{Jordan}

Jordan's gender budgeting effort began in 2010 with assistance from UN Women and the Jordanian National Commission for Women (United States Agency for International Development, 2014). ${ }^{17}$ A pilot project targeted seven ministries, and the objectives included categorizing expenditure on women-specific programs, determining the appropriateness of the categorization, and identifying ways to institutionalize gender budgeting. In 2010, the General Budget Department called on all ministries to document the number of female employees by rank. This pilot ended in late 2010 .

\footnotetext{
${ }^{17}$ We thank Reem Hoseh for providing us with documentation regarding Jordan's gender budgeting efforts.
} 
Between 2010 and 2014, little progress was made on gender budgeting (United States Agency for International Development, 2014). However, in 2015, the Jordanian National Commission for Women published the National Network Action Plan to Support Gender Responsive Budget (Jordanian National Commission for Women, 2015). The National Network consists of ministries (including the Ministry of Finance), the House of Representatives and the Senate, the Jordanian National Commission for Women, civil society and private organizations, and international organizations, and promotes knowledge sharing as a means to reduce gender inequality (Jordanian National Commission for Women, 2015). The United States Agency for International Development (2014) notes that the Network did not have funding to carry out this plan; furthermore, most ministries had not received training.

\section{Kazakhstan}

The National Commission for Family Affairs and Gender Policy and UNIFEM started a gender budgeting project with the agreement from the Ministry of the Economy and Budget Planning of Kazakhstan sometime before 2008 (Sartbayeva, 2008). Gender budgeting in Kazakhstan was also designated as an official Millennium Development Goal "to ensure sustainable gender mainstreaming of national planning and budgeting, especially aiming at minimizing the gender wage gap" (UNDP, 2010). The Ust-Kamenogrosk Women's Federation Status advocates for gender budgeting at the local level (Ashikbayev, 2014; Unzhakova and Shakirova, 2006).

\section{West Bank and Gaza}

The Palestinian Authority has established a permanent legislative committee on gender equality, adopted a quota for female parliamentary representation, and developed the Cross-Sectorial National Gender Strategy to encourage gender diversity and reduce discrimination (OECD, 2014). UN Women in West Bank and Gaza has worked with the Ministry of Women's Affairs to expand capacity development on gender budgeting (UN Women, "Results at a Glance", n.d.). In June, 2014, a gender analysis of the budget concluded that Palestinian expenditure policy was gender-blind (Palestinian Initiative for the Promotion of Gobal Dialogue and Democracy, 2014) (Palestinian Initiative for the Promotion of Gobal Dialogue and Democracy, 2010). Additionally, it is reported that the Palestinian Initiative for the Promotion of Global Dialogue and Democracy, a domestic civil society organization, implemented gender responsive budgets in local councils from 2007 to 2010, with the support from Heinrich Boell Foundation and the Deutsche Gesellschaft für Internationale Zusammenarbeit in which the organization trained local politicians (Palestinian Initiative for the Promotion of Gobal Dialogue and Democracy, 2010).

\section{Other gender initiatives in the region}

Algeria, Azerbaijan, Georgia, Lebanon, Tajikistan, and Uzbekistan have had training and workshops in the past, which indicate their interest in gender budgeting. Lebanon, Tunisia, Yemen, and the United Arab Emirates have adopted national gender equality strategies, and 
Lebanon, Kuwait, and Yemen have parliamentary committees devoted to promoting gender equality have parliamentary committees devoted to promoting gender equality (OECD, 2014). Furthermore, several countries (Tunisia, Iraq, and the Palestinian Authority) have adopted quotas to increase female representation in parliaments.

\section{Gender Budgeting in the CurRent Macroeconomic Situation}

The Middle East and North Africa region continues to contend with social unrest, political change, and inequality on many fronts. Oil-exporting nations across the Middle East and Central Asia face lower revenues and higher budget deficits, owing to the fall in oil prices in the past year and a half. Countries in conflict and their neighbors must cope with the multi-faceted impact of refugees and internally displaced citizens. A few rely heavily on aid to finance expenditures. Efforts to implement and improve gender budgeting in the region must be cognizant of the difficult economic challenges prevalent throughout this region. We offer to improve future gender budgeting efforts by focusing on three areas - education, health, and labor force participation.

Gender budgeting efforts have sought to improve women's access to education and health outcomes, and here, governments need to strengthen the coherence of their budgets to ensure that equality of females and males is achieved in these areas. There continues to be a range of discriminatory tax and financial laws in many countries along with legal barriers restricting women's ability to work. In addition, violence against women remains a key problem for women in the region and the laws and systems of justice are inadequate, even though some countries, like Algeria and Morocco, are now addressing this set of issues. Addressing legal restrictions on women's rights will permit women to strengthen their voice in the budget process. However, legal changes must be accompanied by adequate enforcement to ensure these reforms achieve their intended effects.

Morocco and Afghanistan both tried to increase female labor force participation through gender budgeting, yet Morocco saw little change in either the female labor force participation rate or the ratio of the female to male labor force participation rates, while Afghanistan achieved only slight gains. In view of the continued low rate of women's participation in the labor force despite rising education levels in countries in the region, fiscal policies could target hindrances to omen's labor force participation, including better provision of day care for children and support services to reduce women's unpaid time burdens in the home. Targeted subsidies to employers may help overcome the reluctance of employers to employ women and help to break down cultural barriers to women in the workplace.

The existing gender budgeting initiatives of the region did not include changes to tax policies or the structure of the tax system. However, tax policy could have an important role in complementing fiscal policies coming from the spending side (see Box 3 for a discussion on tax policy and gender inequality in oil exporting countries). The first goal should be to ensure that 
any legal discrimination against women, including through discriminatory deductions or exemptions, is removed from income tax laws. In the case of Morocco specifically, there is a clear bias against women in claiming a dependent deduction. Income tax systems should be mindful of how progressive rate schedules can lead to higher effective tax rates on secondary earners, which tend to discourage married women from working. In addition, the countries should ensure that the burden of indirect taxation, chiefly the value added tax, is designed to avoid being overly regressive and does not fall more heavily on female-headed households. A judicious restructuring of the value added tax to incorporate a limited number of exemptions or zero ratings or reduced rates to benefit these households, consonant with other tax policy goals, should be considered in any subsequent tax reform efforts.

The Afghan gender budgeting effort encouraged all ministries to allocate no less than 30 percent of their development and operations budget gender-related agendas. However, we note some concerns about the structure of the program. While it may be valuable to encourage all ministries to earmark funds for women's advancement and gender inequality reduction, it is unclear if setting the same baseline for all ministries with different needs is appropriate, and this is likely to have been one weakness of the Afghan effort.

Finally, we offer additional recommendations for future gender budgeting initiatives in the region. New efforts would benefit from introducing gender-related considerations into the regular budgetary process; for example, countries might enact into legal requirements for a form of gender budgeting and ensure that spending ministries (and subnational levels of government) address gender-related issues through the budgets by formalizing budget statements and call circulars to include gender-oriented themes. Some form of monitoring of outcomes is also necessary to ensure that ministries comply with the intentions of government. Future initiatives should seek to increase the role of civil society and parliaments, as much of the current effort seems to be centered at the ministry levels. Strengthening sex-disaggregated data collection can help to improve the quality of analytical assessments, supporting good fiscal policies. 


\section{Box 3. Gender Inequality and Revenues in Oil-Exporting Countries}

Tax revenues in oil exporting countries warrants additional consideration. Figure 5 illustrates the dependence of these countries on oil revenues. Total revenue exceeded total expenditure, in the 2010-2013 period on average because of the oil revenues. However, oil prices have declined sharply over the last few years, and these countries are now confronting a worsened fiscal balance and the need to reduce spending. For the six countries in the Gulf Cooperation Council (GCC) (Bahrain, Kuwait, Oman, Qatar, Saudi Arabia, and the United Arab Emirates), the IMF estimated a fiscal deficit of 13 percent of GDP in 2015 (IMF, 2015c).

\section{Figure 5. Total Revenues, Expenditures, and Tax Revenues in Oil Exporting Countries (average over 2010-2013)}
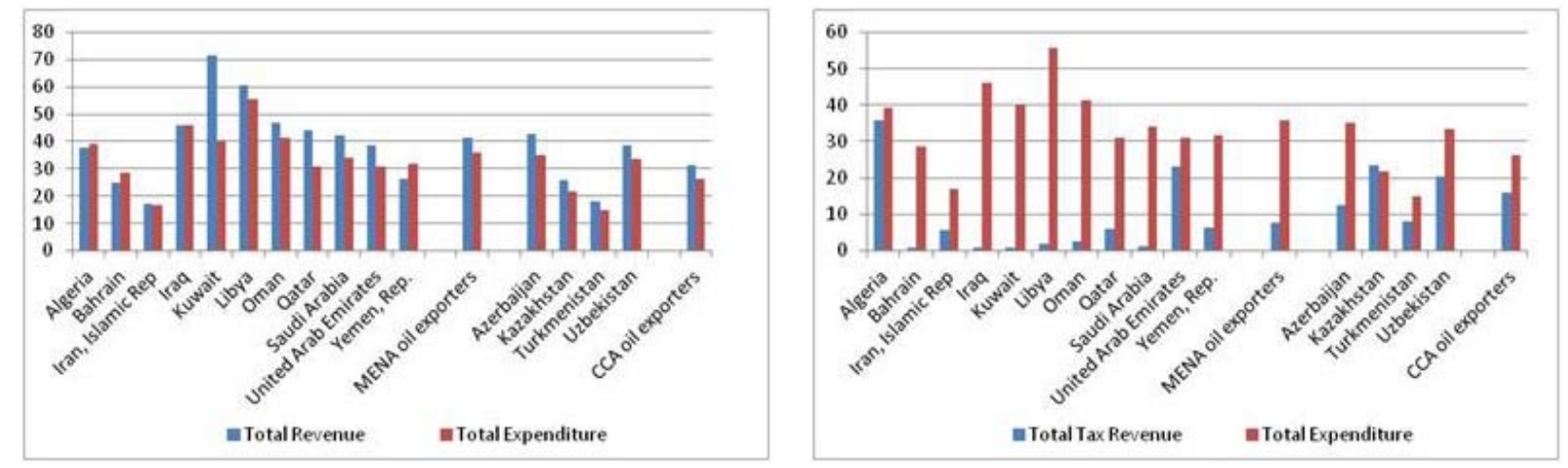

Sources: World Economic Outlook (WEO); and IMF staff calculations.

Should these countries consider adopting gender budgeting given the current outlook for oil prices, they face highly circumscribed spending compared to the past. It is thus important that these countries ensure that spending programs are well-designed and spending targets key programs to address gender equality. At the same time, governments should seek to create incentives for the private sector to reinforce government measures. One recent development is the GCC countries announced that they will introduce a five percent value added tax starting in January 2018, to strengthen revenues. This tax will exempt certain food items, healthcare, and education, which helps reduce regressivity of the tax.

\section{CONCLUSIONS}

Gender budgeting efforts in the Middle East and Central Asia region addressed a number of goals, including improving women's access to education, health, and labor force opportunities. Our survey gender budgeting initiatives in the region found that there were only two countries that have undertaken significant, sustained efforts - Morocco and Afghanistan — and six other examples of gender budgeting initiatives that were less meaningful in terms of results-Armenia, Bahrain, Egypt, Jordan, Kazakhstan and the West Bank and Gaza. Morocco's initiative was the 
most institutionally developed and longstanding, and the country has had success in improving gender parity, particularly in urban areas, although we cannot determine if the success can be attributed to the gender budgeting effort. Afghanistan's initiative was associated with significant progress of Afghan women in certain critical areas, but like Morocco, we are not able to ascertain if gender budgeting was the causal factor. Egypt's initiative was interrupted by the significant economic and political change of recent years.

There is clearly scope for Middle Eastern and Central Asian countries to reduce legal barriers and make more effective use of fiscal policies to address gender inequality and women's development. Gender budgeting efforts aimed to improve women's education and health outcomes, but explicit and implicit discrimination against women is still a fact of life in the region, as evidenced by discriminatory tax and financial laws along with other legal barriers. Despite recent efforts to remove de jure legal restrictions, the lack of enforcement means that many discriminatory laws remain in place.

To increase the low rate of women's labor force participation, fiscal policies could deal with the lack of support services to reduce women's unpaid time burdens in the home and improve access to and the affordability of childcare and elder care. Targeted employer subsidies could be used to overcome cultural barriers and encourage employers to hire more women. Tax policies that result in a disincentive for married women to participate in paid work should be addressed.

It is not enough for countries to aspire to improve the potential of women to contribute to economic life and enjoy a high quality of life; national budgets must also reflect these aspirations through well-targeted interventions, which include increasing allocations to key areas of women's underdevelopment, restructuring incentives, and redistributing through well-designed fiscal policies. The potential of improved fiscal policies to contribute to economic growth through a more active role of women in all areas of life is significant. 


\section{REFERENCES}

Abu-Ghaida, Dina and Stephan Klasen. 2004. "The costs of missing the Millennium Development Goal on gender equity," World Development, Vol. 32, No. 7, pp. 10751107.

Afghanistan Ministry of Finance. (2009, 2014, 2015). National Budget Statements. Afghanistan Ministry of Finance.

Afghanistan Ministry of Women's Affairs. (2005). National Action Plan for the Women of Afghanistan (NAPWA). Afghanistan Ministry of Women's Affairs.

Afghanistan Research and Evaluation Unit. (2013). Women's Rights, Gender Equality, and Transition: Securing gains, moving forward.

Al-Bana, Muhammed. 2010. Egypt's Gender Budgeting Initiative: Where we stand now and what's next? Egypt Ministry of Finance.

Alvi, Hayat. 2011. "Women in Afghanistan: A Human Rights Tragedy Ten Years after 9/11," Human Rights and Human Welfare Working Papers No. 66, University of Denver.

Ashikbayev, Yerzhan. December 26, 2014. "Kazakhstan Implements Millennium Development Goals," Astana Times. <http://astanatimes.com/2014/12/kazakhstan-implementsmillennium-development-goals/>

Barro, Robert J. and Xavier Sala-i-Martin. 2003. Economic Growth. MIT Press Books.

Bloom, David. E., Michael Kuhn, and Klaus Prettner. 2015. "The Contribution of Female Health to Economic Development," NBER Working Paper Series No. 21411. National Bureau of Economic Research.

Bloom, David E., David Canning, and Jaypee Sevilla. 2001. "The Effect of Health on Economic Growth: Theory and Evidence,” NBER Working Paper Series No. 8587. National Bureau of Economic Research.

Budgetary and Human Rights Observatory. 2009. Gender-Sensitive Budget in Egypt 2002-2007. Budgetary and Human Rights Observatory.

Budlender, Debbie and Guy Hewitt. 2003. Engendering Budgets: A Practitioners' Guide to Understanding and Implementing Gender-Responsive Budgets (London: Commonwealth Secretariat).

Budlender, Debbie and Rhonda Sharp, with Kerri Allen. 1998. How to do a GenderSensitive Budget Analysis: Contemporary Research and Analysis (Commonwealth Secretariat and the Australian Agency for International Development).

Cavalcanti, Tiago and Jose Tavares. 2016. "The Output Cost of Gender Discrimination: A Model-based Macroeconomics Estimate,” Economic Journal, Vol. 126, No. 590, pp. 109134. 
Central Agency for Public Mobilization and Statistics. 2015. Statistical Yearbook. Central Agency for Public Mobilization and Statistics (Egypt).

Chafiki, Mohamed and Zineb Touimi-Benjelloun. 2007. "Gender Responsive Budgets in Morocco: Illustration of the Paris Declaration alignment and ownership principles." United Nations Children's rights and Emergency Relief Organization (UNICEF). $<$ http://www.unicef.org/policyanalysis/files/Morocco_GR_budgets.pdf $>$

Constitute Project. 2012. Morocco's Constitution of 2011. $<$ https://www.constituteproject.org/constitution/Morocco_2011.pdf $>$

Cuberes, David and Marc Teignier. 2014. "Aggregate Costs of Gender Gaps in the Labor Market: A Quantitative Estimate.” Universitat de Barcelona Economics Working Paper 2014/308.

Economic Development and Research Center. (2010). Gender Responsive Budget and Gender State in Armenia. Yerevan: EDRC.

Egypt Ministry of Finance. (2009). Egypt's Program in Performance based Budget from a Gender Perspective 2006-2009 [PowerPoint slides]. Egypt Ministry of Finance. $<$ https://www.oecd.org/mena/governance/44216158.pdf $>$

El Bouazzaoui, Ahmed, Abdessalam Fazouane, Hind Jalal, and Salama Saidi. 2010. "Gender equality and taxation in Morocco," in C. Grown, and I. Valodia, Taxation and Gender Equality: A Comparative Analysis of Direct and Indirect Taxes in Developing and Developed Countries (pp. 179-205). IDRC.

Elborgh-Woytek, Katrin, Monique Newiak, Kalpana Kochhar, Stefania Fabrizio, Kangni Kpodar, Phillippe Wingender, and Gerd Schwartz. 2013. "Women, Work, and the Economy: Macroeconomic Grains from Gender Equity.” IMF Staff Discussion Note $13 / 10$.

Elson, Diane. 2002. "Integrating Gender into Government Budgets within a Context of Economic Reform," in D. Budlender, D. Elson, G. Hewitt, and T. Mukhopadhyay, Gender Budgets Make Cents: Understanding gender responsive budgets. 23-48: Commonwealth Secretariat. . 2003. "Gender mainstreaming and gender budgeting." Gender Equality and Europe's Future. Women's Budget Group.

Equality for Peace and Democracy. 2014. Independent Review of Afghanistan 1394 Draft National Budget. EPD.

Esim, Simel. 2011. "Gender Responsive Budgeting for Gender Equality in the Arab Region." Workshop on Gender Responsive Budgeting in the UAE. Dubai. $<$ https://www.academia.edu/1292407/Gender_Responsive_Budgeting_for_Gender_Equal ity_in_Arab_States?auto=download $>$ 
Esteve-Volart, Berta. 2004. "Gender Discrimination and Growth: Theory and Evidence from India,” London School of Economics STICERD Research Paper No. DEDPS 42. $<$ http://sticerd.1se.ac.uk/dps/de/dedps42.pdf>

Forbes, Kristin. 2000. "A Reassessment of the Relationship between Inequality and Growth." American Economic Review, Vol. 90, No. 4, pp. 896-887.

Goldin, Claudia. 1994. The U-shaped female labor force function in economic development and economic history. NBER Working Paper No. 4707. National Bureau of Economic Research.

Gonzales, Christian, Sonali Jain-Chandra, Kalpana Kochhar, and Monique Newiak. 2015. "Fair Play: More Equal Laws Boost Female Labor Force Participation.” IMF Staff Discussion Note $15 / 02$.

Government of Bahrain. 2004. Response to the Questionnaire on the Implementation of the Beijing Platform for Action and the Outcome of the 23rd Special Session of the General Assembly. UN Women.

$<$ http://www.un.org/womenwatch/daw/Review/english/responses.htm>

Harutyunyan, Karine. 2011. "Gender Budgeting: Case of Armenia." Economic Development and Research Center. <http://old.edrc.am/WP/GRB_English_Final.pdf>

International Monetary Fund (IMF). November 2013. Regional Economic Outlook: Middle East and Central Asia. (Washington: International Monetary Fund)

. 2014. "Arab Countries in Transition: Economic Outlook and Key Challenges”

(Washington: International Monetary Fund)

. 2015a. "IMF Engagement with Countries in Post-conflict and Fragile Situations -

Stocktaking." (Washington: International Monetary Fund)

. 2015b. Regional Economic Outlook: Middle East and Central Asia (Washington: International Monetary Fund)

. 2015c. "Tax Policy Reforms in the GCC Countries: Now and How?" (Washington:

International Monetary Fund)

. Various years. World Economic Outlook. (Washington: International Monetary Fund)

Jewell, Andrew, Mario Mansour, Pritha Mitra, and Carlo Sdralevich. 2016. "Fair Taxation in the Middle East and North Africa.” IMF Staff Discussion Note 15/16.

Jordanian National Commission for Women. 2015. The National Network Action Plan to Support Gender Responsive Budget in Jordan. JNCW.

Khatab, Abdullah Shahatah andSaleh Al-Shiekh. 2010. Gender Responsive Budgeting in EgyptAnalytical Reading. Egypt Ministry of Finance. 
Klasen, Stephan. 2002. "Low Schooling for Girls, Slower Growth for All? Cross-Country Evidence on the Effect of Gender Inequality in Education on Economic Development." The World Bank Economic Review, Vol. 16, No. 3, pp. 345-373.

Klasen, Stephan and Francesca Lamanna. 2009. "The Impact of Gender Inequality in Education and Employment on Economic Growth: New Evidence for a Panel of Countries." Feminist Economics, Vol. 15, No. 3 pp. 91-132.

Knowles, Stephen, Paula K. Lorgelly, and P. Dorien Owen. 2002. "Are educational gender gaps a brake on economic development? Some cross-country empirical evidence." Oxford Economic Papers 54, pp. 118-149.

Laframboise, Nicole and Tea Trumbic. 2003. "The Effects of Fiscal Policies on the Economic Development of Women in the Middle East and North Africa." IMF Working Paper $03 / 244$.

Woetzel, Jonathan; Madgavkar, Anu; Ellingrud, Kweilin; Labaye, Eric; Devillard, Sandrine; Kutcher, Eric; Manyika, James; Dobbs, Richard; and Krishnan, Mekala. 2015. "The Power of Parity: How Advancing Women's Equality Can Add \$12 Trillion to Global Growth.” McKinsey Global Institute.

Ministry of Economy and Finance of Morocco. 2008. Gender Report. Rabat: Ministry of Economy and Finance of Morocco.

. 2013. Governmental Plan for Gender Equality (2012-2016) [PowerPoint slides].

Retrieved from Retreived from http:/www.slideshare.net/Gobernabilidad/2-presentationmarocco-eng

Organization for Economic Cooperation and Development (OECD). 2010. Progress in Public Management in the Middle East and North Africa: Case Studies on Policy Reform. OECD.

. 2014. Women in Public Life Gender, Law and Policy in the Middle East and North Africa. OECD.

Palestinian Initiative for the Promotion of Gobal Dialogue and Democracy. 2010. "MIFTAH Makes a Difference - 'Gender Responsive Budgets'." Retrieved from MIFTAH.org: http://www.miftah.org/Display.cfm?DocId=22506andCategoryId=33

. (2014). "Review and Discussion on the Palestinian National Budget 2014 from a Gender Perspective.” Policy Meeting. MIFTAH.

Rade, Maurits., Chuck Thiessen, and Marie S. Huber. 2014. "Building a Better Budget: Assessing National Budget Efficiency and Service Delivery in the Ministries of Education and Public Health". Equality for Peace and Democracy.

Reinhard, Viola (ed.). 2010. Gender-Mainstreaming Programme Afghanistan: Case Studies. Deutsche gesellschaft fur Technische Zusammenarbeit (GTZ). 
Sadiqi, Fatima. 2010. "Morocco.” In S. Kelly, and J. Breslin (Eds.), Women's Rights in the Middle East and North Africa: Progress amid Resistance (pp. 311-336). New York: Freedom House.

Sartbayeva, Damira. (2008). Gender Budgeting: Challenges and Perspectives. Increasing Social Orientation of Budgets and Efficiency of Public Expenditures at National and Local Levels in the Best Interests of Children and Families (pp. 142-147). Astana: UNICEF.

Somach, Susan and Deborah Rubin. 2010. Gender Assessment: USAID/Central Asia Republics. DevTech Systems. United States Agency for International Development.

Stotsky, Janet. 2006. “Gender Budgeting.” International Monetary Fund Working Paper 06/232.

Stotsky, Janet. 2016. “Gender Budgeting: Fiscal Context and Current Outcomes.” International Monetary Fund Working Paper 16/149.

Stotsky, Janet, Sakina Shibuya, Lisa Kolovich, and Suhaib Kebhaj. 2016. “Trends in Women's Advancement and Gender Equality,” International Monetary Fund Working Paper 16/21.

UN Women. 2007. "Highlights of Best Practice from Morocco.” New York: UNIFEM. . 2009. "Evaluation Report: UNIFEM's Work on Gender-Responsive Budgeting Gender-Responsive Budgeting Programme: Morocco". New York: UNIFEM. . 2014a. "Morocco's successful case in implementing gender responsive budgets." $<$ http://gender-financing.unwomen.org/en/highlights/gender-responsive-budgets-case-ofmorocco>

. 2014b. "GRB Regional Centers of Excellence: Knowledge Hubs on Gender Responsive Planning and Budgeting."

.2014c. "Budgets respond to the needs of women in Morocco."

$<$ http://www.unwomen.org/en/news/stories/2014/3/budgets-respond-to-the-needs-ofwomen-in-morocco>

. (Unknown). "Results at a Glance." <http://palestine.unwomen.org/en/what-wedo/national-planning-and-budgeting/results-at-a-glance $>$

United Nations Development Program (UNDP). 2010. "Millennium Development Goals in Kazakhstan." UNDP.

United Nations. 2008. "Official list of MDG indicators." $<$ http://mdgs.un.org/unsd/mdg/Host.aspx?Content=indicators/officiallist.htm>

United States Agency for International Development. 2014.” Jordan Fiscal Reform Bridge Activity (JFRBA) Gender Analysis." USAID.

Unzhakova, Irina, and Svetlana Shakirova. 2006. "Introducing a Gender Perspective: A Case Study." Social Watch. <http://www.socialwatch.org/node/11009> 
World Bank. 2011. World Development Report 2012: Gender Equality and Development . Washington, D.C.: World Bank. 2013. MENA Development Report: Opening Doors: Gender Equality and Development in the Middle East and North Africa. Washington, D.C.: World Bank. . 2015a. Women, Business and the Law 2016: Getting to Equal. Washington, D.C.: World Bank. .2015b. MENA Economic Monitor: Inequality, Uprisings, and Conflict in the Arab World. Washington, D.C.: World Bank.

. 2015c. Morocco Mind The Gap: Empowering Women for a More Open, Inclusive and Prosperous Society. World Bank Group.

. Various years. World Development Indicators.

$<\mathrm{http}$ ://databank.worldbank.org/data/home.aspx $>$

World Health Organization. 2015. Health in 2015 from MDGs to SDGs. WHO. 


\section{Appendix A: Indicators of the Gender-Oriented Millennium Development Goals}

Goals and targets

Indicators

Goal 2. Achieve universal primary education

Ensure that, by 2015, 3.1 Net enrolment ratio in primary education children everywhere, boys

Target 3 and girls alike, will be able to complete a full course of primary schooling

3.2 Proportion of pupils starting grade 1 who reach grade 5

3.3 Literacy rate of 15-24-year-olds

Goal 3. Promote gender equality and empower women

4.1 Ratio of girls to boys in primary, secondary and tertiary education

Eliminate gender disparity in primary and secondary

Target 4 education, preferably by 2005, and to all levels of education no later than 2015

4.2 Ratio of literate females to males of 15-to24-year-olds

4.3 Share of women in wage employment in the non-agricultural sector 4.4 Proportion of seats held by women in
national parliament

\section{Goal 5. Improve maternal health}

Reduce by three quarters,

Target 5.A. between 1990 and 2015, the maternal mortality ratio

$\begin{array}{ll}\text { Target 5.B. } & \text { Achieve, by } 2015 \text {, universal } \\ \text { access to reproductive health }\end{array}$
5.1 Maternal mortality ratio

5.2 Proportion of births attended by skilled health personnel

5.3 Contraceptive prevalence rate

5.4 Adolescent birth rate

5.5 Antenatal care coverage (at least one visit and at least four visits)

5.6 Unmet need for family planning

Source: United Nations, 2008. 


\section{Appendix B. Gender Budgeting in the Middle East and Central Asia Data Template}

\begin{tabular}{|c|c|c|c|}
\hline & Afghanistan & Morocco & Egypt \\
\hline \multicolumn{4}{|l|}{ ORIGINS } \\
\hline Does the government have a gender budgeting initiative & Yes & Yes & Yes \\
\hline If yes, start year & 2005 & 2002 & 2005 \\
\hline If any, end year & & & 2011 \\
\hline Supported by international organizations or bilateral aid agencies & Yes & Yes & Yes \\
\hline Tied to Millennium Development Goals or national development plan or gender equality strategy & Yes & Yes & Yes \\
\hline \multicolumn{4}{|l|}{ SELECTED COMPONENTS OF FISCAL POLICY } \\
\hline Focus on spending & Yes & Yes & Yes \\
\hline Spending focus on key human development (education and health) & Yes & Yes & Yes \\
\hline Spending focus on physical infrastructure (transport, water, electricity, and energy) & No & Yes & No \\
\hline Spending focus on justice and security (violence against women, judicial assistance) & No & Yes & No \\
\hline Spending structural reforms (subsidies, transfers, incentive or distributional objectives) & No & No & No \\
\hline Focus on revenue & No & No & No \\
\hline Personal income tax focus & No & No & No \\
\hline Other tax focus, including general or selective sales and trade & No & No & No \\
\hline \multicolumn{4}{|l|}{ INDICATORS TO PLACE GENDER BUDGETING IN THE FISCAL PROCESS } \\
\hline Broad statement of goals of Minister of Finance & Yes & Yes & Yes \\
\hline Gender budgeting statement in budget documentation & Yes & No & Yes \\
\hline Gender budgeting circular or related to instruct the bureaucracy & Yes & No & Yes \\
\hline Gender budgeting in planning and programming & Yes & Yes & Yes \\
\hline Gender budgeting outcome report or audit & No & No & Yes \\
\hline Explicit reporting on gender equality spending & No & Yes & Yes \\
\hline \multicolumn{4}{|l|}{ LEGAL BASIS } \\
\hline Gender budgeting has constitutional standing & No & No & No \\
\hline Gender budgeting is incorporated in organic budget or other finance laws & No & Yes & No \\
\hline \multicolumn{4}{|l|}{ ROLE OF GOVERNMENT } \\
\hline Ministry of Finance lead entity or just involved & Yes & Yes & Yes \\
\hline Other ministries play consequential role and which & Yes & Yes & Yes \\
\hline Subnational government & No & No & Yes \\
\hline \multicolumn{4}{|l|}{ ROLE OF CIVIL SOCIETY } \\
\hline Significant encouragement or participation of civil society & Yes & No & No \\
\hline
\end{tabular}

